\title{
An Archaeological Survey of the Proposed Location of the Bastrop City Wastewater Treatment Plant, Bastrop County, Texas
}

Bruce K. Moses

Follow this and additional works at: https://scholarworks.sfasu.edu/ita

Part of the American Material Culture Commons, Archaeological Anthropology Commons, Environmental Studies Commons, Other American Studies Commons, Other Arts and Humanities Commons, Other History of Art, Architecture, and Archaeology Commons, and the United States History Commons

Tell us how this article helped you.

This Article is brought to you for free and open access by the Center for Regional Heritage Research at SFA ScholarWorks. It has been accepted for inclusion in Index of Texas Archaeology: Open Access Gray Literature from the Lone Star State by an authorized editor of SFA ScholarWorks. For more information, please contact cdsscholarworks@sfasu.edu. 


\section{An Archaeological Survey of the Proposed Location of the Bastrop City Wastewater Treatment Plant, Bastrop County, Texas}

\section{Creative Commons License}

\section{(c) (1) \&}

This work is licensed under a Creative Commons Attribution-NonCommercial 4.0 International License 


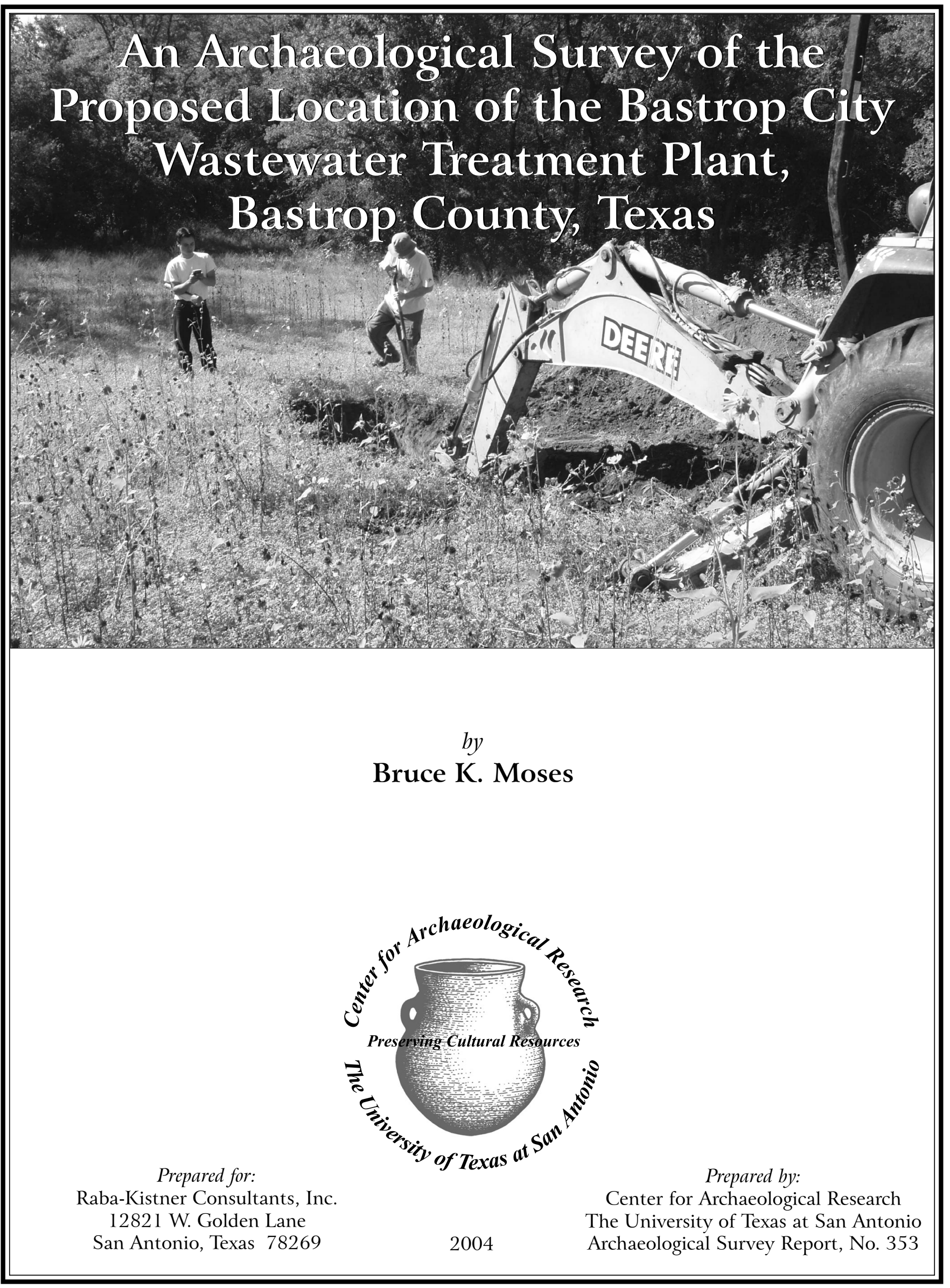




\title{
An Archaeological Survey of the Proposed Location of the Bastrop City Wastewater Treatment Plant, Bastrop County, Texas
}

\author{
by \\ Bruce K. Moses
}

Texas Antiquities Permit No. 3501

Steve A. Tomka

Principal Investigator

Prepared for:

Raba-Kistner Consultants, Inc. 12821 W. Golden Lane

San Antonio, Texas 78269

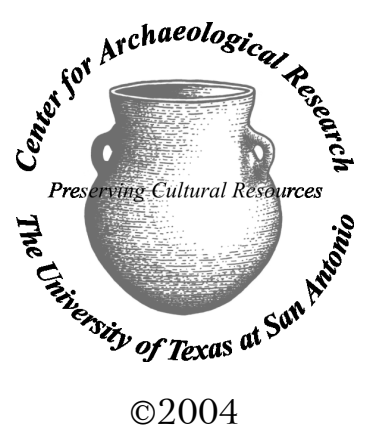

Prepared by:

Center for Archaeological Research The University of Texas at San Antonio Archaeological Survey Report, No. 353 
A list of publications offered by the Center for Archaeological Research is available. Call (210) 458-4378; write to the Center for Archaeological Research, The University of Texas at San Antonio, 6900 N. Loop 1604 W., San Antonio, Texas 78249-0658; e-mail to car@lonestar.utsa.edu; or visit CAR's web site at http:// car.utsa.edu. 


\section{Abstract:}

Between August 11 and August 13, 2004, the Center for Archaeological Research at The University of Texas at San Antonio conducted an archaeological survey of the proposed location for the City of Bastrop Wastewater Treatment Plant in central Bastrop County, Texas. The pedestrian survey was performed for Raba-Kistner Consultants, Inc. on behalf of the City of Bastrop. Construction of the proposed wastewater treatment facility will primarily impact the northwestern portion of the property, although a gray-water outfall line will traverse the property and empty into the Colorado River. The survey, carried out under Texas Antiquities Permit No. 3501 with Dr. Steve A. Tomka serving as Principal Investigator, was performed to identify any cultural deposits present within the project area. The Phase 1 project included a $100 \%$ pedestrian survey of the 26.5 -acre property, the excavation of 27 shovel tests, and the excavation of seven backhoe trenches.

Two archaeological sites, both located on the southern portion of the project area, were identified. Site 41BP678, located at the confluence of the Colorado River and a tributary, Spring Branch, consists of a light surface scatter of chipped stone debitage and buried cultural materials. The results of shovel testing suggest that two components may be present, with one located from the surface down to $20 \mathrm{~cm}$, and a second located between $40 \mathrm{~cm}$ and $60 \mathrm{~cm}$ below surface. No features were identified, though burned rock is present in small numbers. No temporally diagnostic artifacts were recovered. The second site, 41BP679, abuts Spring Branch. This site consists of a light surface scatter of chipped stone, minimally including a biface and a core. Shovel testing demonstrates that debitage and burned rock is present down to $30 \mathrm{~cm}$ below surface, though deeper deposits (ca. $75 \mathrm{~cm}$ to $92 \mathrm{~cm}$ below surface), evidenced by two flakes present in a backhoe trench profile, are present at the site. No features were identified at 41BP679. While no diagnostic artifacts were recovered, a broken biface was collected from the backdirt of a backhoe trench. The highly patinated biface has parallel flaking reminiscent of late Paleoindian (c.f. Angostura) forms.

The proposed wastewater treatment facility will impact limited portions of each of these sites. The gray-water outflow line will cut through roughly $109 \mathrm{~m}$ of 41BP678, and $61 \mathrm{~m}$ of 41BP679. In addition, the construction of one clarifier tank and a flume will directly impact small portions of 41BP679. We currently lack sufficient information on either site to make determinations of eligibility for listing on the National Register of Historic Places or for determining State Archeological Landmark status. If the proposed wastewater treatment facility cannot be moved to avoid these sites, we recommend that limited testing be conducted to determine the eligibility status of 41BP678 and 41BP679.

All artifacts collected during this project are curated at the Center for Archaeological Research according to Texas Historical Commission guidelines. 


\section{Table of Contents:}

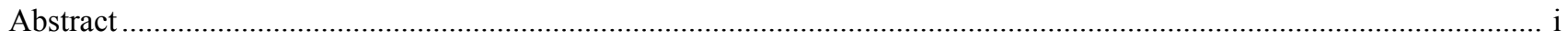

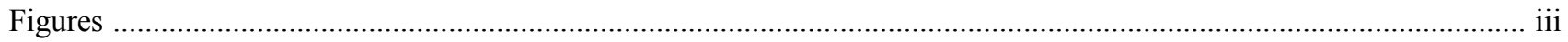

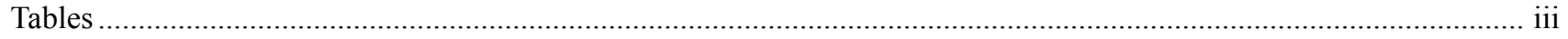

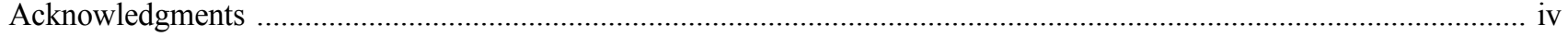

Chapter I: Introduction

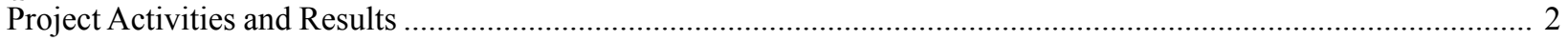

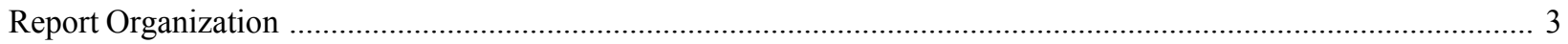

Chapter 2: Project Setting

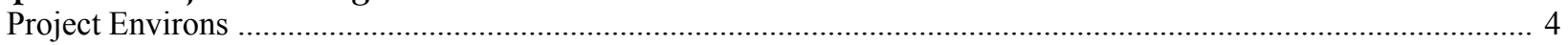

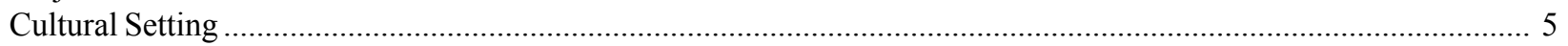

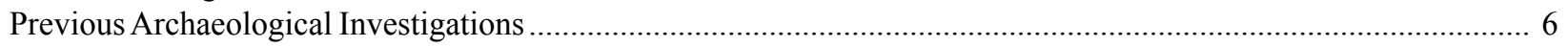

Chapter 3: Methods

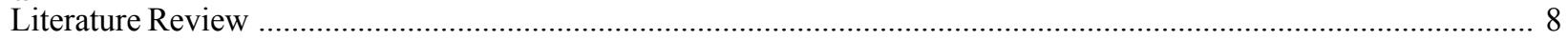

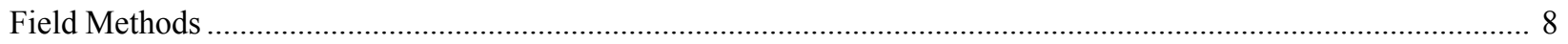

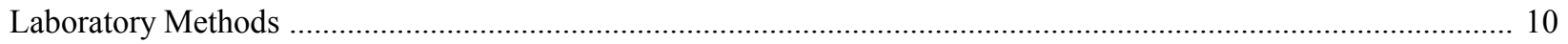

Chapter 4: Results of Investigations

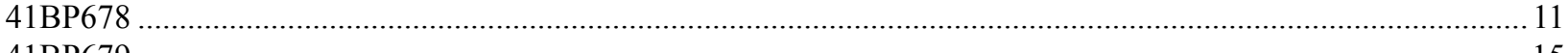

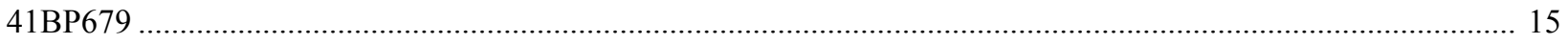

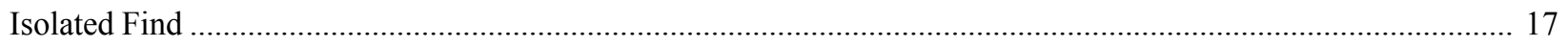

Chapter 5: Recommendations

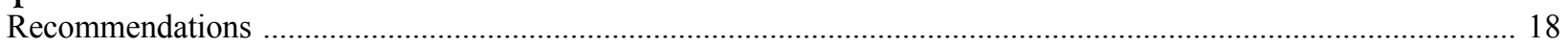

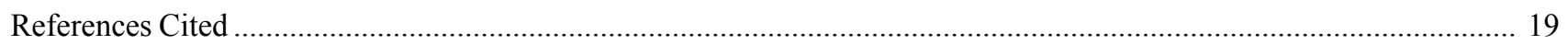




\section{Figures:}

Figure 1-1. Location of project area in central Bastrop County. ........................................................................... 1

Figure 1-2. Project area showing the proposed City of Bastrop Wastewater Treatment Plant and related features. ............ 2

Figure 1-3. Detail of the site plan showing the Area of Potential Effect in the northwestern portion of the project area ... 3

Figure 2-1. Typical vegetation within the survey area in the Colorado River floodplain. ................................................ 4

Figure 2-2. Location of a portion of the previously surveyed area, nearby sites, and the current project boundary. .......... 7

Figure 3-1. Project area showing transects surveyed during the $100 \%$ pedestrian survey ................................................ 8

Figure 3-2. Shovel tests and backhoe trenches excavated within the project area. .......................................................... 9

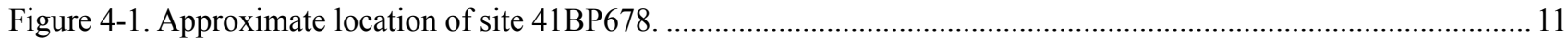

Figure 4-2. Lithic debitage in the western drainage associated with 41BP678 ........................................................... 12

Figure 4-3. Excavation of Shovel Test 2 on 41BP678 near the junction of the Colorado River and Spring Branch. ........ 13

Figure 4-4. Excavation of Backhoe Trench 3 on 41BP678. ............................................................................... 14

Figure 4-5. Profile of a portion of the west wall of Backhoe Trench 3. ....................................................................... 15

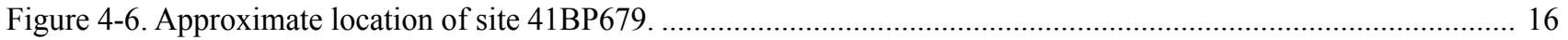

Figure 4-7. Profile of east wall of Backhoe Trench 6 at 41BP679........................................................................... 17

Figure 4-8. Bifaces recovered from Backhoe Trench 6 at 41BP679.................................................................... 17

\section{Tables:}

Table 4-1. Shovel Test Results from 41BP678

Table 4-2. Shovel Test Results from 41BP679 


\section{Acknowledgments:}

Several individuals have contributed to the successful completion of this project. The Center for Archaeological Research (CAR) would like to thank Amy Linnerooth of Raba-Kistner Consultants, Inc. and James Miller of the City of Bastrop for facilitating CAR throughout the project. Mike Fisher of the City of Bastrop was also helpful in providing the construction details for the proposed wastewater treatment plant. Thanks are extended to CAR crew members Leonard Kemp and Jason Perez for their work in the field. Thanks also go to Dr. Raymond Mauldin, CAR Assistant Director, for his insightful comments on the draft of this report and to Dr. Steve Tomka, CAR Director, who served as principal investigator on the project. Rick Young and Bruce Moses drafted the figures in this report. Johanna Hunziker, CAR editor, produced the final version of the report. 


\section{Chapter 1: Introduction}

In August 2004, the Center for Archaeological Research (CAR) at The University of Texas at San Antonio was contracted by Raba-Kistner Consultants, Inc., hereafter the Client, to conduct a $100 \%$ pedestrian survey of the 26.5 acre site of the proposed City of Bastrop wastewater treatment facility in central Bastrop County, Texas (Figure 1-1). This survey was conducted in an effort to identify cultural resources within the property. This work was performed under Texas Antiquities Permit No. 3501, with Dr. Steve Tomka serving as Principal Investigator and Mr. Bruce Moses serving as Project Archaeologist.
The proposed wastewater treatment facility will occupy approximately 4.47 acres of the total 26.5 -acre tract owned by the City of Bastrop. It is bounded on the east by the Colorado River and by a perennial drainage, Spring Branch, to the south (Figure 1-2). The proposed wastewater treatment plant and the Area of Potential Effect (APE) will consist of an entrance drive and parking areas, a lift station, a maintenance building, and primary, secondary, and tertiary treatment facilities to be constructed in the northwestern portion of the property (Figure 1-3). An additional 430-mlong outfall pipe will be installed across the central and

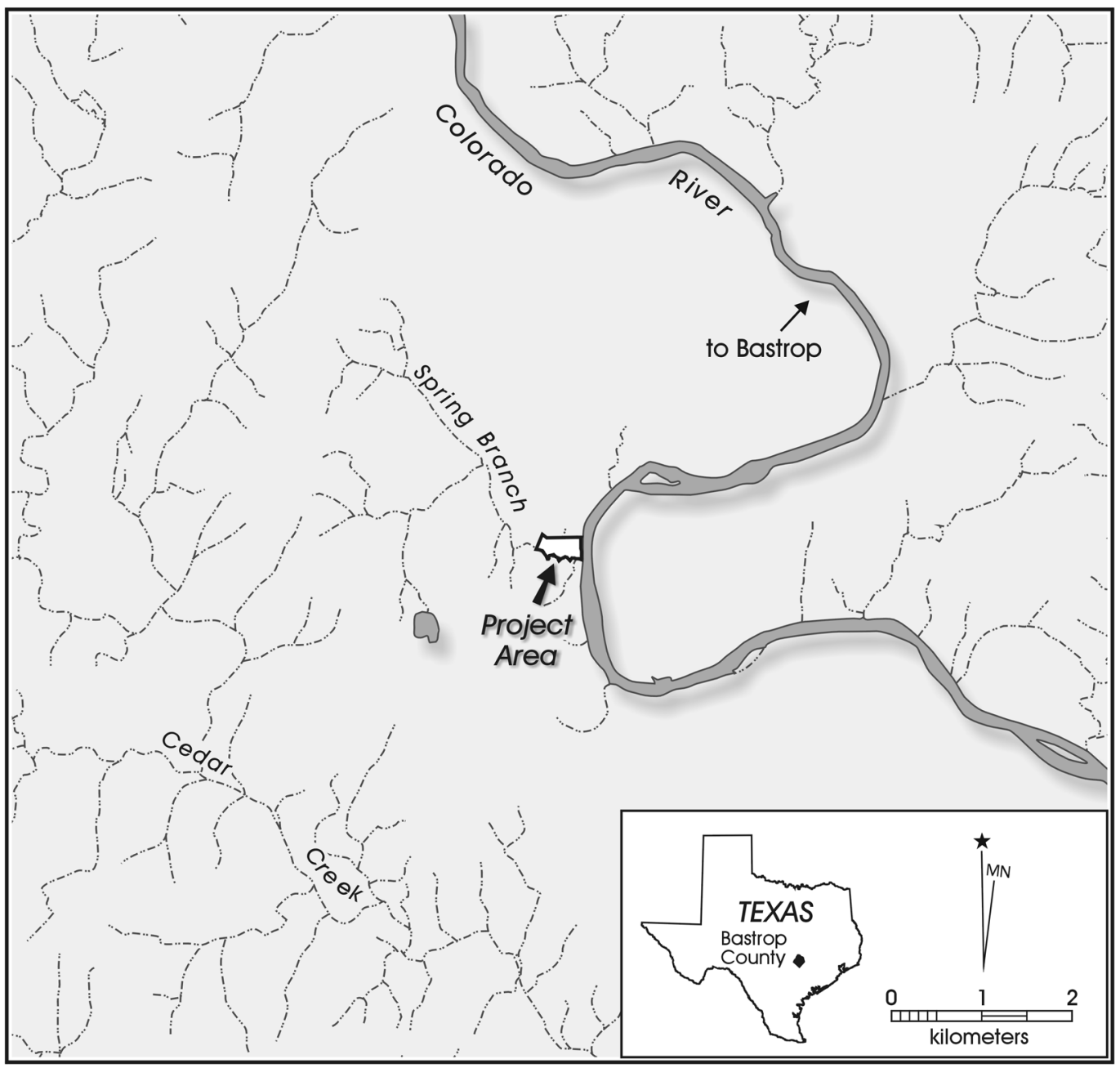

Figure 1-1. Location of project area in central Bastrop County. 


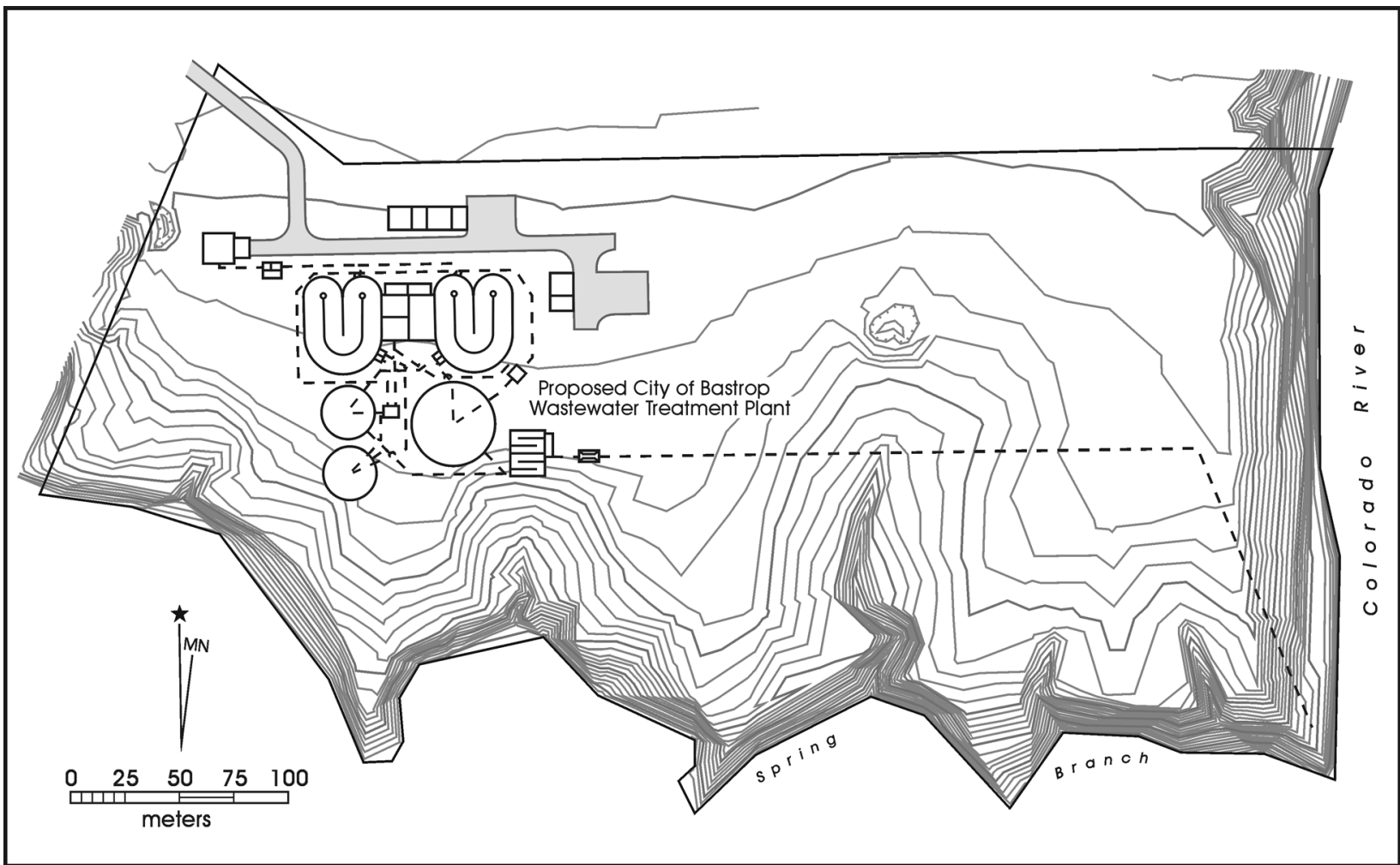

Figure 1-2. Project area showing the proposed City of Bastrop Wastewater Treatment Plant and related features.

eastern portions of the property to empty effluent discharge into the Colorado River near its intersection with Spring Branch at the southeastern corner of the property. Within this APE, the construction of two circular clarifier tanks will require extensive excavation ranging from 4 feet $(1.2$ $\mathrm{m})$ deep for the southern tank to 12 feet $(3.67 \mathrm{~m})$ deep at the concrete wall of the northernmost tank. The construction of a Parshall flume, a small rectangular structure used for flow measurement, will require excavation approximately 3 feet deep $(0.9 \mathrm{~m})$. The outfall pipe will originate at the flume and will require a maximum excavation to about 3 feet $(0.9 \mathrm{~m})$. This discharge pipe will be 18 inches $(0.9 \mathrm{~m})$ in diameter and is expected to extend for approximately 700 feet $(213 \mathrm{~m})$.

This project area was previously investigated in 1985 and 1986 as part of a larger regional survey (Robinson 1987). While no cultural remains were identified within the current project area at that time, one archaeological site (41BP311) was recorded adjacent to the property on the southern bank of Spring Branch. While the current project area was surveyed, apparently no subsurface testing was ever conducted within the area, as no mention of such is made in the report (Robinson 1987).

\section{Project Activities and Results}

The current project consisted of a $100 \%$ pedestrian survey of the 26.5-acre property, and the excavation of 27 shovel tests and seven backhoe trenches. Two archaeological sites, both located on the southern portion of the project area, were identified. Site 41BP678, located at the confluence of the Colorado River and a tributary, Spring Branch, consists of a light surface scatter of chipped stone debitage and buried archaeological remains. Shovel testing results suggest that two components may be present, with one located from the surface down to $20 \mathrm{~cm}$ below surface (cmbs), and a second located between $40 \mathrm{cmbs}$ and $60 \mathrm{cmbs}$. While burned rock was recovered from the site, no features or diagnostic artifacts were present, and neither component can be dated. A second site (41BP679) abuts Spring Branch. The site consists of a light surface scatter of chipped stone, including a biface and a core. Shovel testing suggests that debitage and burned rock is present down to $30 \mathrm{cmbs}$, though deeper deposits (ca. 75-92 cmbs), evidenced by two flakes present in a backhoe trench profile, are present at the site. No features were recorded. No diagnostic artifacts were present; however, a broken, highly patinated biface recovered from the backdirt of a backhoe trench has parallel flaking reminiscent 
of late Paleoindian (c.f. Angostura) forms. Small portions of both sites will be impacted by the construction of the proposed wastewater treatment facility. We currently lack sufficient information on either site to make determinations of eligibility for listing on the National Register of Historic Places or for determining State Archeological Landmark status. Therefore, if the proposed water treatment facility cannot be moved to avoid these sites, we recommend that limited testing be conducted to determine the eligibility status of $41 \mathrm{BP} 678$ and $41 \mathrm{BP} 679$.

\section{Report Organization}

This report consists of five chapters. Following this introductory chapter, Chapter 2 provides an overview of the project area and summarizes the archaeological knowledge about the region. Chapter 3 discusses the methods employed, including the background literature review, field methods, and laboratory methods. The results of this archaeological survey are presented in Chapter 4. Chapter 5 summarizes the work and provides project recommendations.

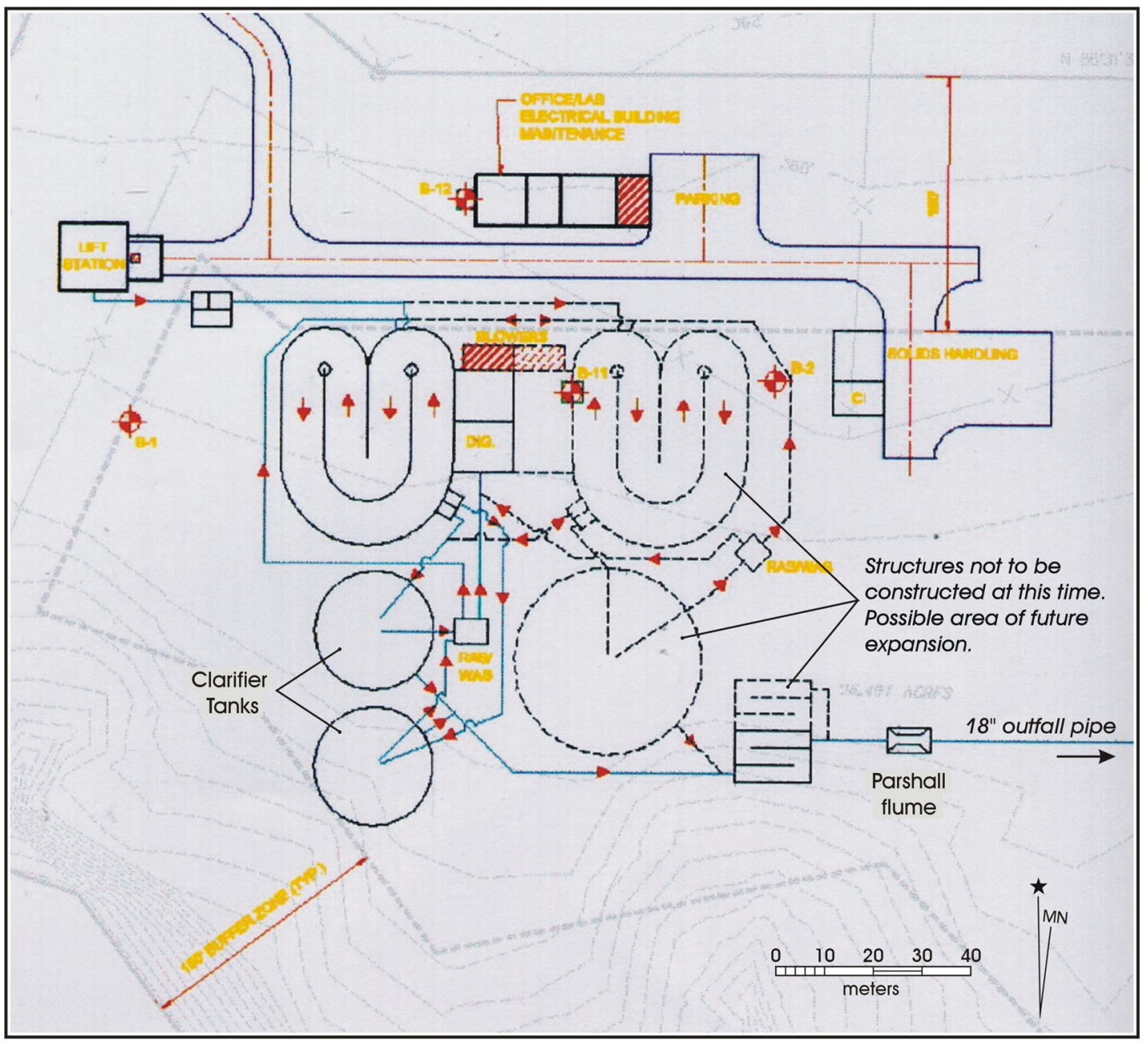

Figure 1-3. Detail of the site plan showing the Area of Potential Effect in the northwestern portion of the project area. 


\section{Chapter 2: Project Setting}

This chapter describes the location, climate, flora, fauna, and geology of the project area. Also included is a discussion of the culture history of the region and previous archaeological work conducted in the immediate area.

\section{Project Environs}

The project area is located on the 1982 Bastrop 7.5 minute USGS quadrangle map, just southeast of the Edwards Plateau below the Balcones Escarpment along the Colorado River. Climate in this region is typically humid and subtropical with cool winters and hot summers (Baker 1979). Rainfall distribution is almost even throughout the year with a slight increase between April and June and again in September. Average annual rainfall for Bastrop County is 37.18 inches (Baker 1979). Temperatures range from an average low of $58.2^{\circ} \mathrm{F}$ to an average high of $78.9^{\circ} \mathrm{F}$ (Baker 1979). The annual growing season in Bastrop County is 206 days (The Handbook of Texas Online 2002).

Gould (1969:11) classifies the region largely as a Post Oak Savannah floral province. In this regime, non-pastured area vegetation consists largely of post oak (Quercus stellata) and blackjack oak (Q. marilandica) with some black hickory (Carya texana) dominating the upper story. The understory consists of flora typical of tall grass prairies, which are dominated by little bluestem (Schizachyrium scoparium). Also present in the understory are switchgrass (Panicum virgatum), purpletop (Tridens flavus), silver bluestem (Bothriochloa saccharoides), and Texas wintergrass (Stipa leucotricha). Portions of the project area nearer to the Colorado River floodplain include more water-tolerant hardwoods such as ash (Fraxinus americana), pecan (Carya illinoinensis), water elm (Planera aquatica), hackberry (Celtis laevigata), water oak ( $Q$. nigra), willow oak $(Q$. phellos), cottonwood (Populus deltoides), and black willow (Salix nigra; Figure 2-1).

Bastrop County falls within the Texan biotic province (Blair 1950). The common mammalian species found in this region include white-tailed deer (Odocoileus virginianus), eastern cottontail rabbit (Sylvilagus floridanus), raccoon (Procyon lotor), opossum (Didelphis virginiana), and fox squirrel (Sciurus niger). There are also numerous bird species common throughout the county including the northern bobwhite (Colinus virginianus), eastern meadowlark (Sturnella magna), mourning dove (Zenaida macroura),

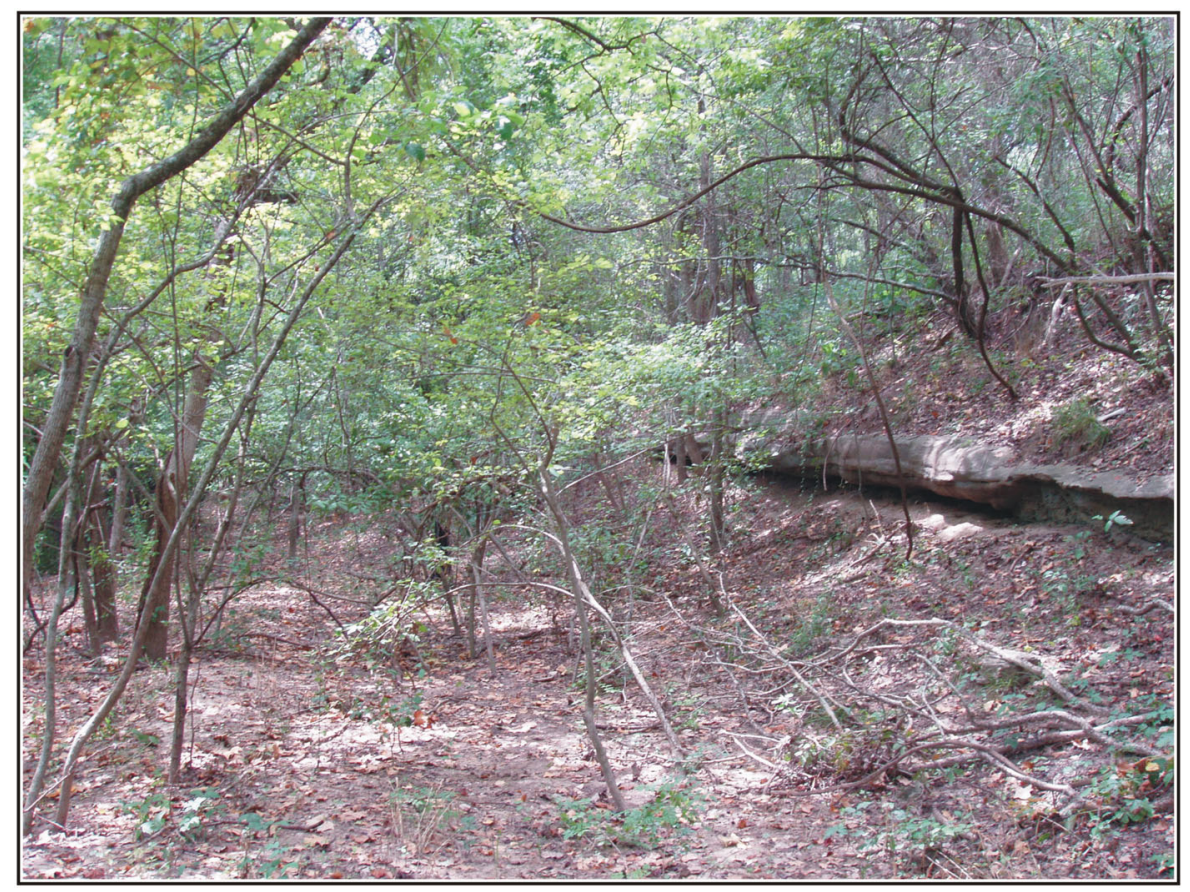

Figure 2-1. Typical vegetation within the survey area in the Colorado River floodplain. 
killdeer (Charadrius vociferous), field sparrow (Spizella pusilla), red-tailed hawk (Buteo jamaicensis), and belted kingfisher (Ceryle alcyon).

The geologic strata exposed within the project area consist primarily of fluviatile terrace deposits laid down during the late Pleistocene. The Colorado River's winding dendritic pattern of tributary streams has filled the river valley with as much as 70 feet $(21 \mathrm{~m})$ of sediment in some places. Combinations of gravel, sand, silt and clay in varying proportions overlying older Cretaceous and Tertiary strata generally characterize these alluvial sediments. Along the Colorado River these gravels include dolomite, limestone, chert, and quartz from the Edwards Plateau as well as various igneous and metamorphic rocks from the Llano region. Approximately $1.5 \mathrm{~km}$ west-northwest of the survey area, outcroppings of Calvert Bluff Formation, a Tertiary mudstone with varying amounts of sandstone and lignite, are common. Rocks from the Simsboro Formation are also present to the northwest and are composed of mostly sand, some mudstone, clay, and mudstone conglomerate (Barnes 1974). Chert nodules and plates are common in Edwards limestone outcroppings located some $50 \mathrm{~km}$ to the northwest.

The project area is primarily composed of Bosque and Shep series soils associated with the lower terraces of the Colorado River. Bosque soils occur on relatively flat but dissected terraces averaging $40-50$ feet (12-15 m) above the current river level. The upper portions of Bosque series soils are composed of loam and transition to clay loam with depth (Baker 1979). These Mollisols have a dark-colored surface layer that is high in organic matter and are commonly found beneath prairie grass in North America.

Topographically, the proposed wastewater treatment facility will be situated on the $\mathrm{T} 2$ terrace of the Colorado River on the western bank (cutbank side) of Haupt Bend. Elevations in the project area range from 315 to 365 feet AMSL. A large portion of the 26.5-acre area (approximately 50.7\%) shows evidence of recent plowing, and at the time of the survey, was overgrown in sunflower (Helianthus annuиs).

\section{Cultural Setting}

In Central Texas, researchers have been able to document a long prehistoric sequence that can be broken down into four major time periods: Paleoindian, Archaic, Late Prehistoric, and Historic (Black 1989; Collins 1995; Prewitt 1981). These periods are often further divided into subperiods that can be distinguished by changing material cultures. Each of these time periods is briefly discussed here to illustrate the general archaeological potential of the region.

\section{Paleoindian}

The Paleoindian period (11,500-8800 BP) is often divided into early and late subperiods, each corresponding with changes in projectile point styles. Clovis and Folsom point types, and bifacial Clear Fork tools and finely flaked end scrapers characterize the early Paleoindian period (Black 1989). The first stemmed points (i.e., Wilson), as opposed to lanceolate points (i.e., Angostura and Golondrina), begin to appear during the late Paleoindian period. It has often been assumed that the earliest Native Americans subsisted primarily on large game including mastodon, mammoth, and bison antiquus. However, recent research from the WilsonLeonard Site in Central Texas (Collins 1998) and fresh perspectives on Paleoindian adaptation (e.g., Tankersley and Isaac 1990) suggest that the diet of these early inhabitants may have been much broader.

In Central Texas many of the sites containing Paleoindian materials are found on high terraces, valley margins, and upland locations (Black 1989). This seems to fit with a broader pattern of Paleoindian site distributions where sites are located on landforms providing views of the surrounding landscape, are centered on critical resource zones, or are found in highly productive resource areas (Tankersley and Isaac 1990). Common Paleoindian locations include camp, kill, quarry, cache, ritual, and burial sites. Projectile points are also often recovered as isolated finds from a variety of landforms (Hester 1995).

\section{Archaic}

The Archaic period (8800-1200 BP) is identified as a period of intensification of hunting and gathering and a move toward greater exploitation of local resources. As a result, we see a broadening of the material culture, including the "extensive use of heated rock" in cooking (Collins 1995: 383). Food processing technologies appeared to have broadened as features such as hearths, ovens and middens increase during this time (Black and McGraw 1985). Large cemeteries also appeared during this period signaling the likely establishment of regional "territories" (Black and McGraw 1985).

The Early, Middle, and Late Archaic subperiods correspond with changes in climatic conditions and resource availability and are distinguished by differences in diagnostic projectile points (Collins 1995). During the Early Archaic (8800-5000 
BP), a variety of Early Corner-Notched (Uvalde, Martindale, Baker) and then later Early Basal-Notched (Bell, Andice) points appeared across Central Texas. Early Archaic sites are often recorded on river terraces or on hills overlooking valleys (Hester 1995:439). A new suite of temporally diagnostic artifacts are associated with the onset of the Middle Archaic (5000-2400 BP) including Pedernales, Langtry, Kinney, and Bulverde point types as well as triangular bifaces and tubular stone pipes (Black 1989; Hester 1995). In addition to the upland settings, Middle Archaic campsites are commonly located on floodplains, low terraces, and natural levees. The Late Archaic (2400-1200 BP) is characterized by the presence of Shumla, Ensor, Montell, and Marcos point types. Late Archaic sites are usually located near modern stream channels and occur in all topographic settings (Black 1989; Hester 1995).

\section{Late Prehistoric}

The Late Prehistoric period (1200-350 BP) in Central Texas marks a distinctive shift from the use of the atlatl and dart points to the use of the bow and arrow points. This period is further subdivided into early and late intervals termed the Austin and Toyah, respectively.

The Austin Interval occurred between $1200 \mathrm{BP}$ and $650 \mathrm{BP}$ (Prewitt 1981) and is marked by several temporal diagnostics including Scallorn and Edwards arrow points. The introduction of ceramics to Central Texas coincides with the beginning of the Toyah Interval, which spans the final three centuries of the Late Prehistoric. Perdiz and Cliffton points are diagnostic projectile points of the Toyah Interval.

\section{Historic}

The Historic period in Central Texas begins with the arrival of Europeans in the late seventeenth century. The Central Texas region quickly became a focal point of conflict as the northward expansion of Spanish influence began to clash with the southward push of the Comanche and later the Apache. The result of this conflict was the displacement of many indigenous groups including, ultimately, the Tonkawa Indians of Central Texas. Decimated by disease brought by Europeans, many of the remaining groups sought refuge in the numerous Spanish missions established early in the eighteenth century.

Mission life had a significant impact on the beliefs, lifeways, and material culture of the hunter-gatherers. The European influence can be seen in the artifact assemblages from this time and include ceramics, metal and glass. However, preHispanic Goliad ware and lithic artifacts (arrow points and scrapers) are also evident in the archaeological record. In Bastrop County, the early Historic period was highlighted by Spanish entradas across the region including those by Domingo Terán de los Rios in 1691, Pedro de Aguirre in 1709, and Louis Jucherean St. Denis in 1714. In 1804 a small Spanish fort, Puesta de Colorado, was constructed at the Camino Real crossing of the Colorado River approximately $4 \mathrm{~km}$ from the current project area (Leffler 2001).

\section{Previous Archaeological Investigations}

Among the earliest attempts to document prehistoric life in the region is A. M. Wilson's (1930) unsystematic survey of Bastrop and Wilson counties. Unfortunately, Wilson's sketchy descriptions and lack of reliable provenience data make it all but impossible to relocate many of the sites accurately on state site file maps (Bement 1989; Klinger et al. 1999). In 1953, T. B. Campbell and E. R. Jelks, of the University of Texas at Austin, excavated two Late Prehistoric burials at 41BP1 (Skelton and Freeman 1979:21). Seventeen additional sites were recorded and tested in Bastrop County between 1962 and 1968 by the University of Texas at Austin. The most notable of these are the McCormick Site (41BP3), the Pease Site (41BP5), and several sites near the Powell Bend Prospect along Big Sandy Creek (Kenmotsu 1982). In 1972, Paul Duke located the Thunderbird Lake Site (41BP78) near Smithville and recorded an extensive lithic concentration with diagnostic artifacts that included Paleoindian and Late Prehistoric specimens (Duke 1977). A number of cultural resources studies have also been carried out at Camp Swift in the northern portion of the county. These archaeological studies have contributed a comprehensive record regarding all stages of Bastrop County prehistory (Nickels et al. 2003; Robinson et al. 2001; Schmidt and Cruse 1995; Skelton and Freeman 1979).

In 1985 and 1986, David G. Robinson and Solveig A. Turpin, in association with the Texas Archeological Survey of the University of Texas at Austin, carried out an archaeological survey of selected lowland riverine zones in Bastrop County as a part of the Bastrop County Historical Commission's Sesquicentennial Project (Figure 2-2; Robinson 1987). That project included the current project area. Although no archaeological sites were observed within the current project boundary, four archaeological sites were identified to the south of the project area on the banks of the Colorado River. 


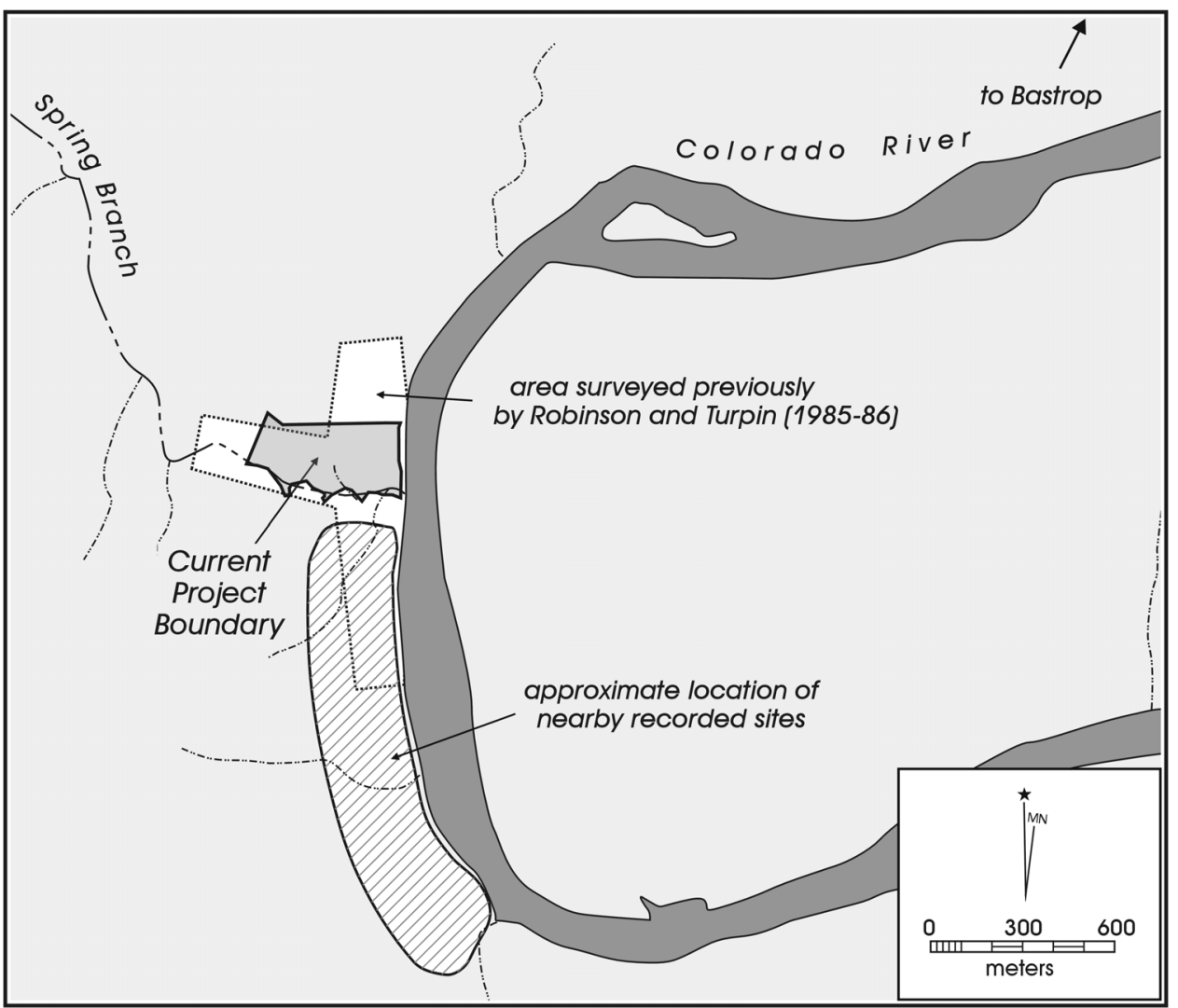

Figure 2-2. Location of a portion of the previously surveyed area (Robinson 1987), nearby recorded sites, and the current project boundary.

Site 41BP311 is the largest and closest of these sites to the project area. It is located on the southern bank of Spring Branch. The site consists of copious amounts of lithic debitage, burned rock, deer bones and shell scattered across approximately 10 acres. A single shovel test was placed within the site boundary. Cultural materials were observed to a depth of $30 \mathrm{~cm}$ in gravel pit profiles (Texas Historical Commission [THC] 2004). A single looter's excavation pit was observed on site. The site is assumed to be of Archaic age, although no temporally diagnostic artifacts have been recovered. Immediately south of 41BP311, a second prehistoric site was recorded, 41BP50. Here, a buried midden was exposed in a gravel pit excavated by a bulldozer. Choppers, cores, debitage, finished bifaces and a Clear Fork gouge were reported as having been recovered from 41BP50. Site 41BP51 was identified farther south of 41BP50. This is also a buried site, identified in a ditch excavated for pipe installation. A number of dart point types were recovered from the ditch backdirt and at least one of the specimens is a Paleoindian point while another is an
Archaic Carrizo type (Turner and Hester 1999:84). It is unclear exactly how deep the artifacts were buried. The southern-most site in the vicinity of the project area recorded by Robinson is 41BP48. This site was identified from a surface scatter of artifacts, although some of the materials appeared to be shallowly buried. Large quantities of burned rock, lithic debitage and bifaces were present on surface. Paleoindian, Archaic, and Late Prehistoric temporally diagnostic artifacts were collected from 41BP48.

While all four of the sites are located outside of the current project area, the fact that at least three of them contain buried deposits suggests that they have some research value. Unfortunately, the level of work conducted on these sites at the time of their discovery was not sufficient to establish whether they have stratified or disturbed components. The presence of Paleoindian and later diagnostic artifacts indicates a long span of use and occupation of the region. Furthermore, the evidence of looters' excavations suggests these resources are in danger of additional impacts. 


\section{Chapter 3: Methods}

The Center for Archaeological Research was contracted to conduct the following fieldwork: (1) a $100 \%$ pedestrian survey of the 26.5 -acre property to ascertain whether any hitherto undocumented cultural resources would be impacted by the proposed development of the wastewater treatment plant; (2) shovel testing of the project area at a rate of one shovel test per two acres of land and an additional maximum of eight shovel tests per each site discovered to define site boundaries; and (3) backhoe trenching along the banks of the Colorado River and its confluence with Spring Branch.

\section{Literature Review}

The archaeological research commenced with a comprehensive review of all available archaeological reports and databases to identify and characterize all archaeological sites known to occur in the vicinity of the project area. Much of the compilation of the known prehistoric and historic sites in the vicinity of the project area was based on the Texas Archeological Sites Atlas (THC 2004), the Texas Historic Sites Atlas, and THC map files.

\section{Field Methods}

An archaeological survey was carried out to identify any surface-exposed or buried archaeological deposits within the APE. Fieldwork within the APE consisted of a $100 \%$ pedestrian survey, shovel testing and backhoe trenching. During the survey portion of the fieldwork, the CAR crew traversed the project area along $30-\mathrm{m}$ transects (Figure 3-1). Aerial photographs with clearly marked transects and hand-held compasses were used to orient crew members.

Shovel testing was conducted on 21.4 of the 26.5 acres subject to the $100 \%$ surface survey. The remaining portion of the acreage occurs on steep slopes and embankments or

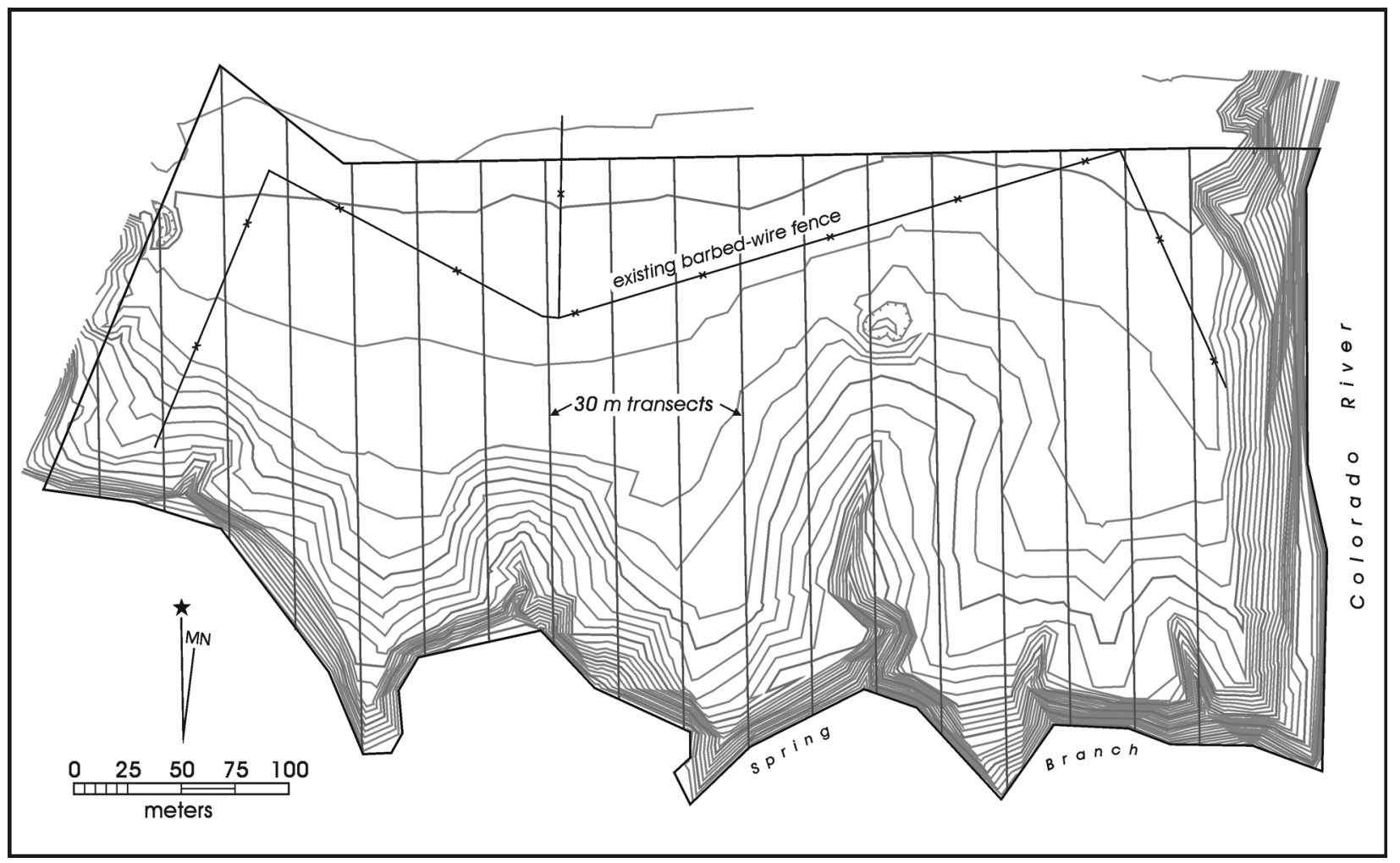

Figure 3-1. Project area showing transects surveyed during the 100\% pedestrian survey. 
Archaeological Survey for the Bastrop Wastewater Plant

within the current floodplain of the Colorado River. No shovel tests were excavated in these areas, however, selected areas such as cutbanks were inspected for the presence of buried archaeological deposits and/or surface artifacts. Initially, shovel tests were spaced evenly across the project area to conform to THC standard requirements for archaeological survey at an average rate of one shovel test for every two acres. Additional shovel tests were later placed on landforms thought likely to yield evidence of prehistoric cultural material (Figure 3-2). Shovel tests were $30-35 \mathrm{~cm}$ in diameter and extended to a depth of $60 \mathrm{cmbs}$. All were excavated in $10-\mathrm{cm}$ levels and soil from each level was screened through $1 / 4$-inch hardware cloth and all recovered artifacts were bagged and labeled by provenience for laboratory processing, analysis, and curation. A standard shovel test form was completed for every excavated shovel test. Data collected from each shovel test included the final excavation depth, a tally of all materials recovered from each 10-cm level, and a brief soil description (texture, consistence, color, inclusions). The location of each shovel test was recorded using a Trimble GeoExplorer II Global Positioning System (GPS) unit. Shovel test locations also were sketched onto an aerial photograph as a backup to GPS provenience information. Any additional observations considered pertinent were included as comments on the shovel test excavation forms and/or in field notes.

The placement of seven backhoe trenches across the survey area was designed to test a representative portion of the project area and to prospect for significant cultural features, deposits, or discrete paleosols. To comply with the Minimum Survey Standards as defined by the THC, each backhoe trench was at minimum $1 \mathrm{~m}$ wide and $10 \mathrm{~m}$ long. These dimensions were maintained until roughly $1.6 \mathrm{~m}$ below ground surface. At that time, the archaeologist entered the trench to inspect the wall profile for cultural materials. General descriptions were then made of each of the excavated trenches including a record of soil morphology and cultural material content. A detailed wall profile was recorded for two of the backhoe trenches. Three of the seven trenches (BHT 3, BHT 6, and BHT 7) were then excavated to a depth of $2.5 \mathrm{~m}$ below ground surface. These deeper excavations were conducted in accordance with Occupational Safety and Health Administration (OSHA) standards

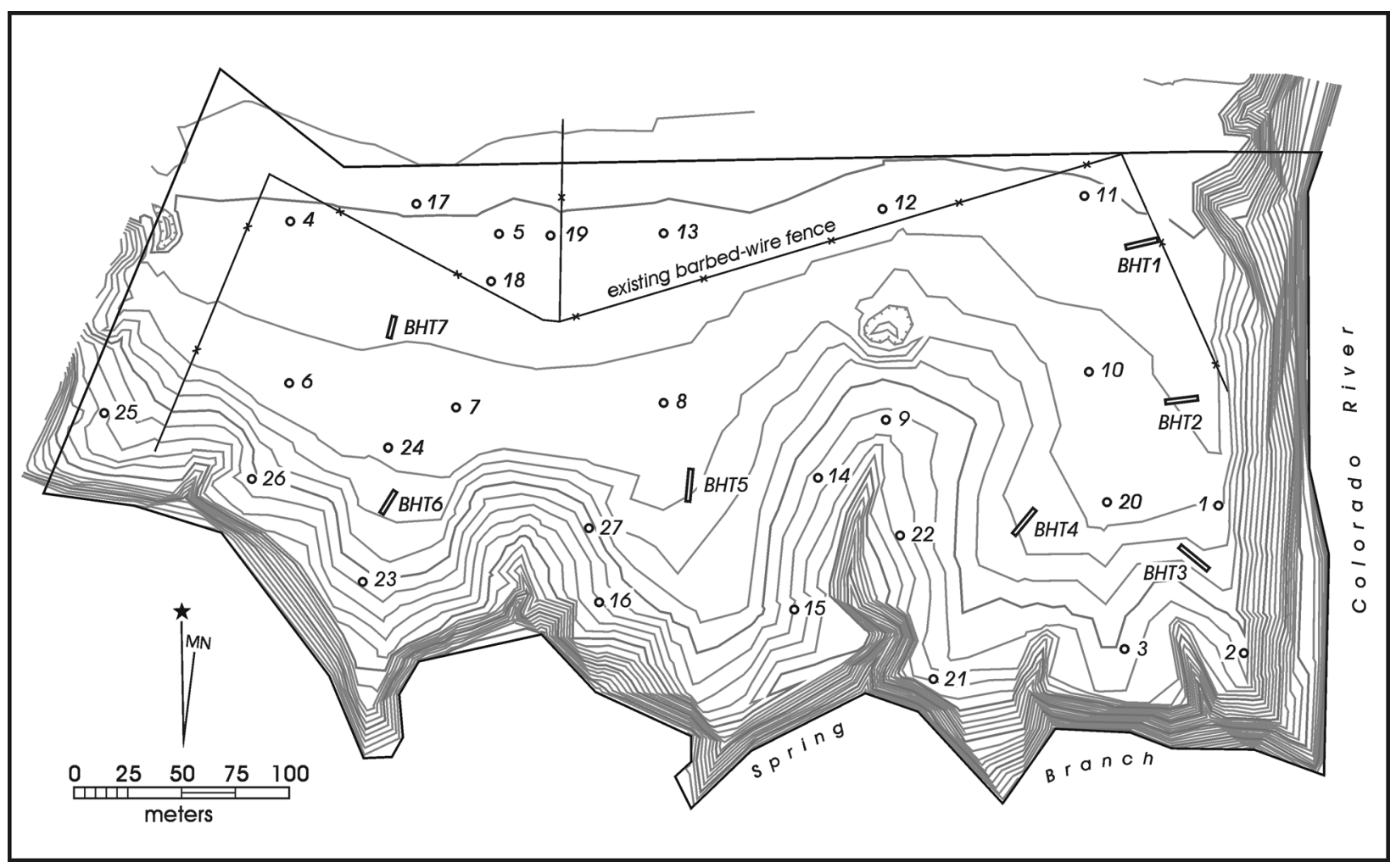

Figure 3-2. Shovel tests and backhoe trenches excavated within the project area. 
for protection of employees in excavations (29 CFR 1926.652). No archaeologist entered the trench at this time and all observations were carried out from the surface. None of the matrix removed via mechanical means was screened, but sediments were inspected for artifacts upon excavation.

Artifacts in trench walls and backdirt were recorded but not collected - except in the case of BHT 6 where a possible Paleoindian point and numerous cultural remains were collected from the backdirt.

For the purpose of this survey, newly encountered sites were defined as locations potentially having at least five artifacts within a $30-\mathrm{m}^{2}$ area, or as a location containing a single cultural feature such as a hearth. All other artifacts were classified as isolated occurrences. Texas Site Forms were prepared for all newly documented sites on the project.

\section{Laboratory Methods}

All cultural material collected during the survey was prepared in accordance with federal regulation 36 CFR part 79 , and in accordance with current guidelines of the Center for Archaeological Research. Processing of recovered artifacts began with washing and sorting them into appropriate analytical categories (e.g., debitage, tools, burned rock, etc.). Artifacts were placed into archival-quality bags, given a specific catalog number and then entered into an Excel $^{\mathbb{}}$ spreadsheet. Acid-free labels were placed in all artifact bags. Each label contains a provenience or corresponding lot number. Lithic tools were labeled with archivalquality pigment ink and covered by a clear coat of Acryloid B-72. In addition, all of the chipped stone artifacts were labeled with the appropriate provenience data. Artifacts were separated by class and stored in acid-free boxes. Boxes were labeled with standard labels.

Field notes, forms, and drawings were placed in labeled archivally stable folders. Documents and forms were printed on acid-free paper. A copy of the survey report and all computer disks pertaining to the investigation are stored in an archival folder and curated with the field notes and documents. 


\section{Chapter 4: Results of Investigations}

Twenty-seven shovel tests and seven backhoe trenches were placed within the project area. With one exception, all shovel tests were excavated to a depth of $60 \mathrm{cmbs}$. Sediments in the top $20 \mathrm{~cm}$ were generally a compact silt/sand and transitioned downward into a hard-to-very hard silt/clay. Seven of the 27 shovel tests $(26 \%)$ had cultural material present. While backhoe trench fill was not screened, artifacts were observed in five trenches; BHT 2, BHT 3, BHT 4, BHT 5, and BHT 6. The survey identified two prehistoric archaeological sites (41BP678 and 41BP679) and a single isolated find recorded in a shovel test.

\section{$41 \mathrm{BP} 678$}

Site 41BP678 is located on the northwest side of the confluence of the Colorado River and Spring Branch (Figure 4-1). 41BP678 extends almost $200 \mathrm{~m}$ east-west and ranges from $145 \mathrm{~m}$ north-south near the Colorado River to $45 \mathrm{~m}$ near the site's western edge. The total area of 41BP678 is 4.56 acres ( 1.85 hectares). Roughly $80 \%$ of the site is an open field that is currently covered in sunflower and was likely plowed in the recent past. The remaining portion of $41 \mathrm{BP} 678$ is dominated by various hardwood species

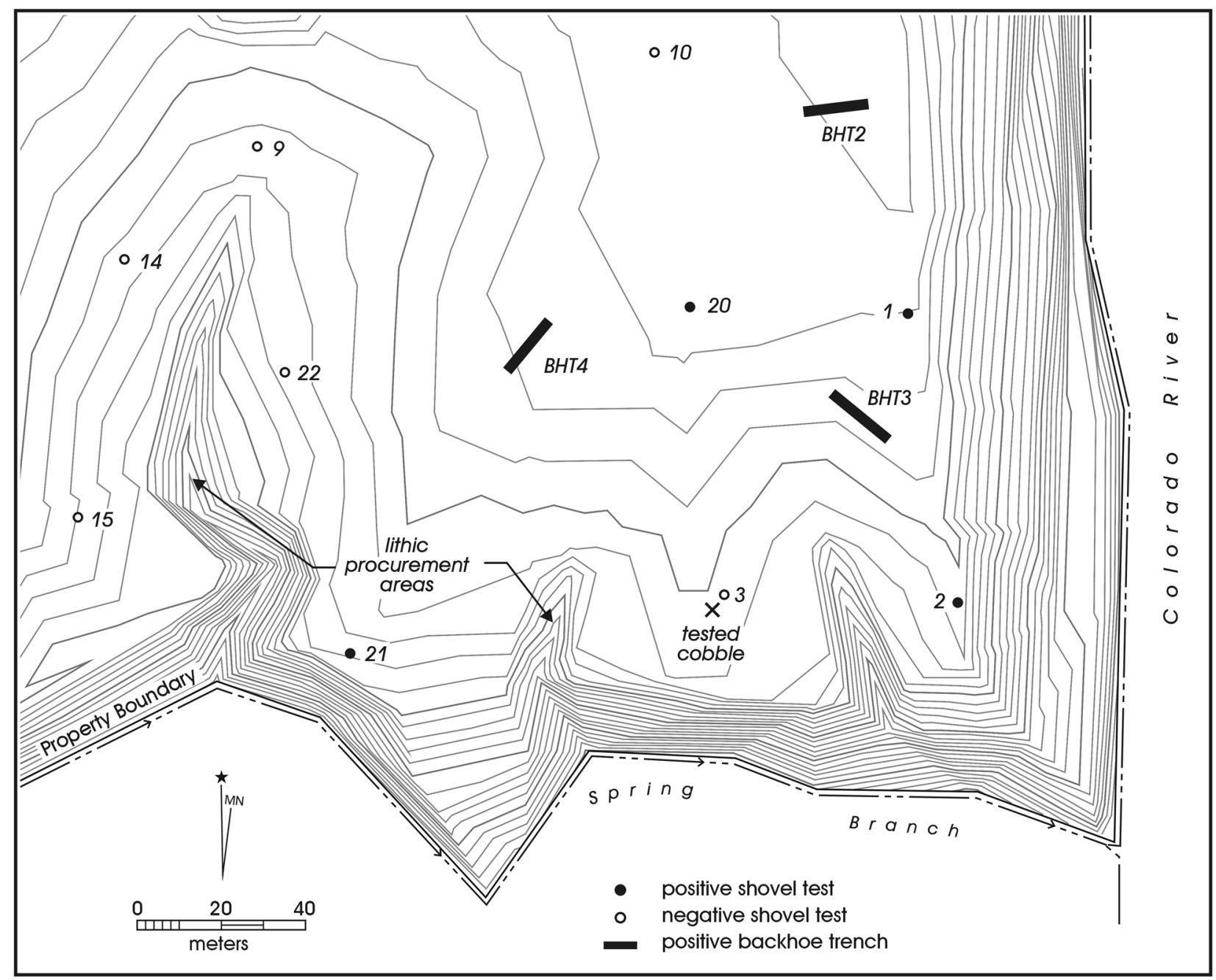

Figure 4-1. Approximate location of site 41BP678. 
including ash, pecan, water elm, hackberry, water oak, willow oak, hickory and cottonwood. Surface visibility was low $(\sim 20 \%)$ in both the open field and the wooded areas.

The site consists of a light surface scatter of lithics across the upland landform and this scatter extends to the edge of the bluff to the south and east. A single piece of burned rock was recorded on the surface at the southwestern portion of the site, and about two-dozen lithic artifacts, including cores, tested cobbles, and primary and secondary flakes, were observed in an adjacent drainage (Figure 4-2). This scatter extends for almost $40 \mathrm{~m}$ along the drainage, which appears to have been used as a lithic procurement area. A similar lithic scatter was also observed in a second drainage some $70 \mathrm{~m}$ east of the first scatter (Figure 4-1).

Four $(80 \%)$ of the five shovel tests excavated on 41BP678 contained cultural material (Figure 4-1). In all, six pieces of debitage, two pieces of burned rock, and two mussel shell fragments were recovered from the four positive shovel tests (Table 4-1). Two shovel tests (ST 1 and ST 2) were excavated near the eastern bluff overlooking the Colorado River

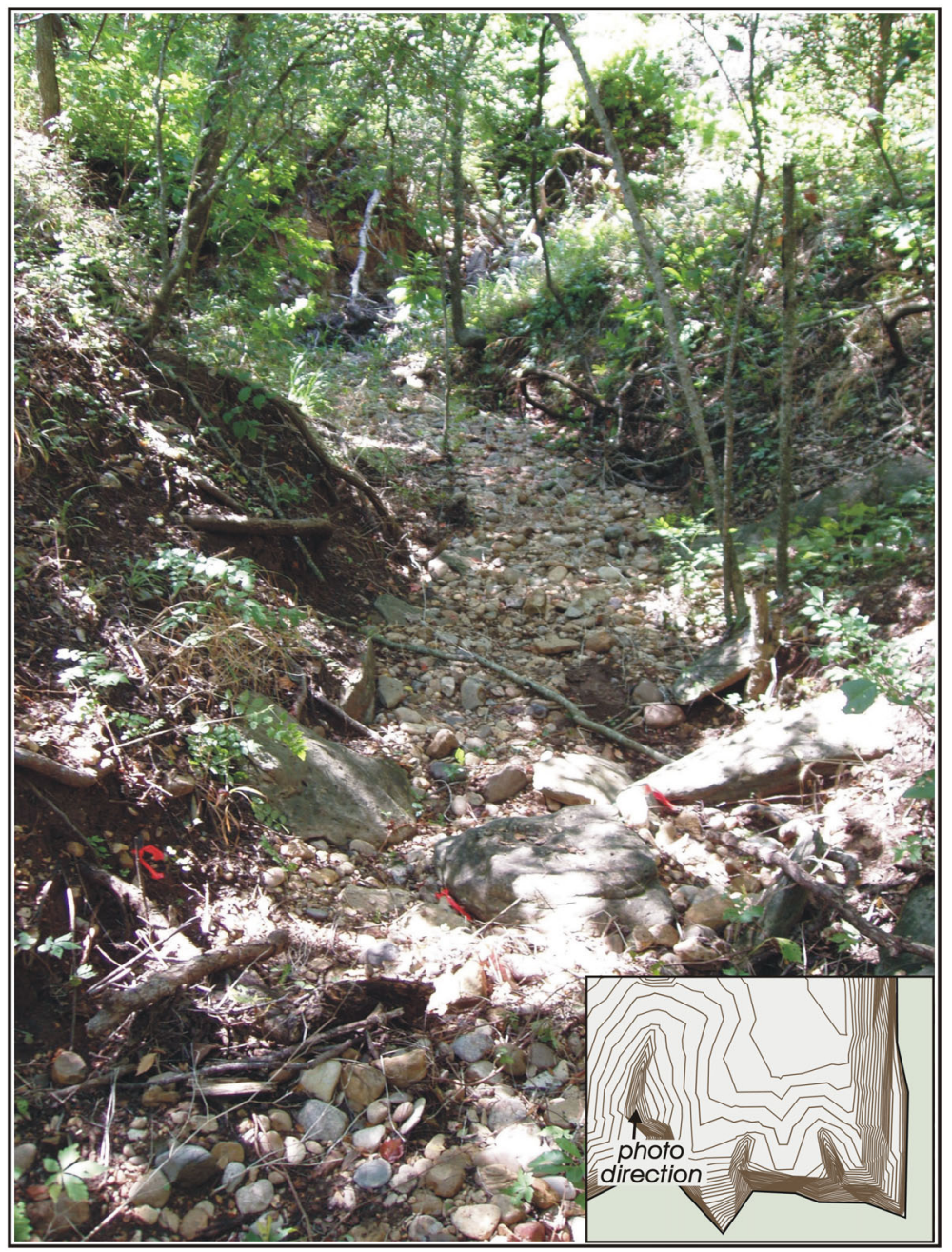

Figure 4-2. Lithic debitage in the western drainage associated with 41 BP678. Ribbon in foreground marks modified lithic materials. 
Table 4-1. Shovel Test Results from 41BP678

\begin{tabular}{|c|l|c|c|}
\hline Shovel Test No. & \multicolumn{1}{|c|}{ Artifact } & Count & Level of Artifact (cmbs) \\
\hline 1 & Burned Rock & 1 & $5(40-50)$ \\
\hline 2 & Debitage & 1 & $5(40-50)$ \\
\hline 2 & Debitage & 2 & $6(50-60)$ \\
\hline 2 & Mussel Shell & 1 & $6(50-60)$ \\
\hline 2 & Burned Rock & 1 & $6(50-60)$ \\
\hline 20 & Debitage & 2 & $2(10-20)$ \\
\hline 20 & Mussel Shell & 1 & $2(10-20)$ \\
\hline 21 & Debitage & 1 & $2(10-20)$ \\
\hline
\end{tabular}

(Figures 4-1 and 4-3). Burned rock was recovered from ST 1 from $40-50 \mathrm{cmbs}$. Lithic debitage and burned rock were recovered from ST 2 between $40 \mathrm{cmbs}$ and $60 \mathrm{cmbs}$. Debitage was also observed on the surface near each of these excavations. ST 20 was placed about $50 \mathrm{~m}$ west of ST 1 in order to ascertain the presence and depth of cultural deposits between ST 1 and BHT 4 (Figure 4-1). Two flakes were recovered from this shovel test from $10-20 \mathrm{cmbs}$. ST 21 was excavated near the bluff in the southwest corner of the site and produced a single flake from 10-20 cmbs. A fifth shovel test, ST 3, was also excavated near the bluff along the southern portion of the site but did not contain cultural materials. A large tested cobble, however, was observed on the surface in the immediate vicinity of ST 3.

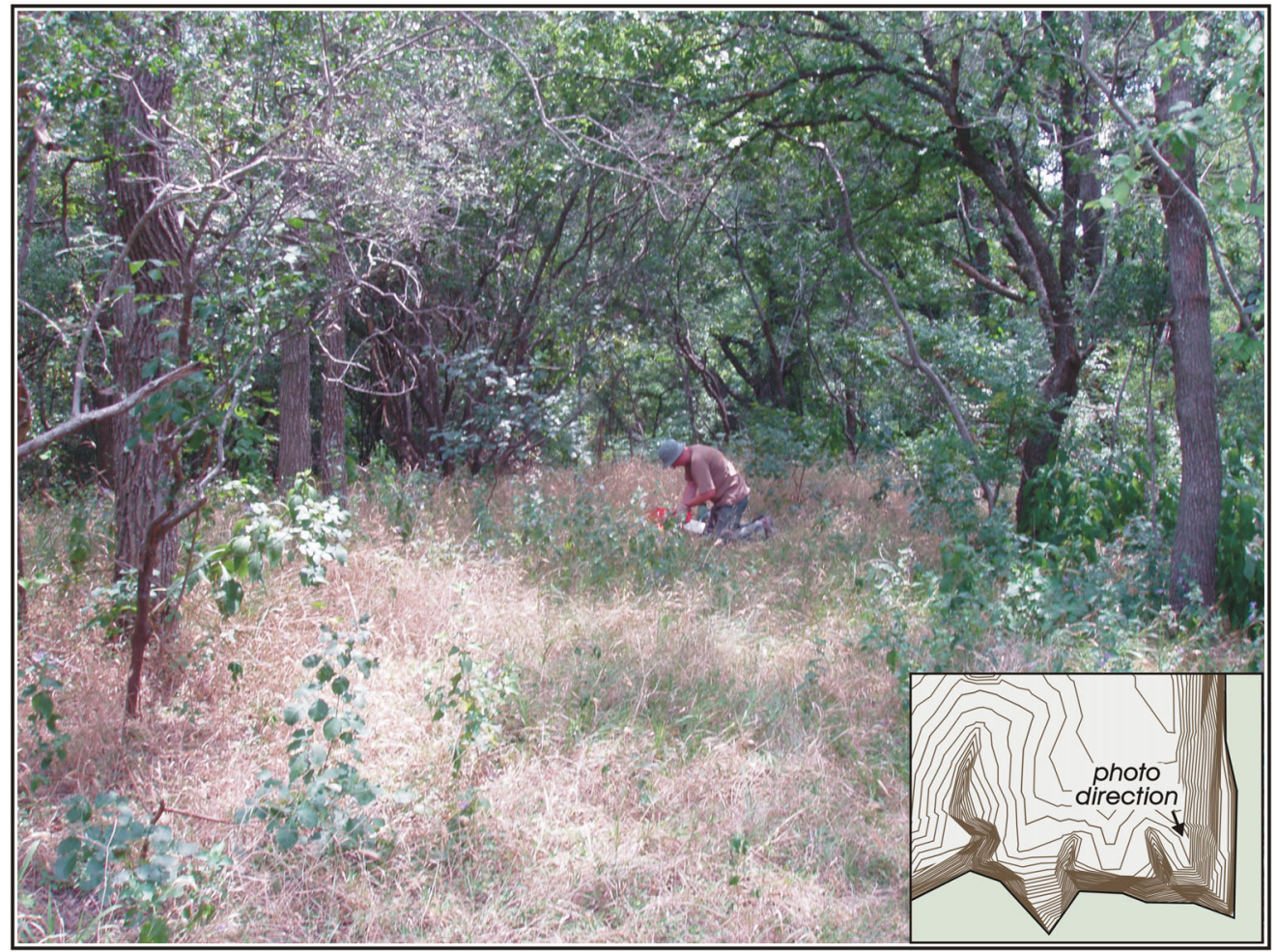

Figure 4-3. Excavation of Shovel Test 2 on 41 BP678 near the junction of the Colorado River and Spring Branch. 
Three backhoe trenches excavated within the site boundary also contained cultural materials (Figure 4-1). BHT 2 was placed along the bluff of the Colorado River approximately $50 \mathrm{~m}$ north of ST 1 and was positive for cultural artifacts including small quantities of lithic debitage, a single burned rock fragment and bone observed in the backdirt. In addition, snails (Rabdotus) were present at varying depths from the surface to $65 \mathrm{cmbs}$. Thus, BHT 2 forms the northern-most positive excavation within 41BP678. BHT 3 was located between ST 1 and ST 2 near the eastern edge of the site (Figures 4-1 and 4-4). Artifacts observed in the backdirt included one tested cobble and one piece of heavily patinated cortical debitage. No artifacts were observed in situ. Sediments in this area were markedly different than those observed in other portions of the APE and included a thick Bt horizon of gravelly sand/clay that contained several thick lenses of developing calcium carbonate (Figure 4-5). BHT 4 was placed on a low rise to the northwest of BHT 3 in order to test areas farther away from the drainages. A single flake was observed in the backdirt, though no cultural material was observed in situ. Rabdotus shells were recorded from the surface to $50 \mathrm{cmbs}$.

\section{Summary}

Results of the testing conducted at 41BP678 suggest the possible presence of two prehistoric components. The first component likely includes artifacts observed across the surface and extending to $20 \mathrm{cmbs}$. A second component was only observed in shovel tests in the southeastern portion of the site (ST 1 and ST 2) and occurs between $40 \mathrm{cmbs}$ and $60 \mathrm{cmbs}$. No features were observed at this site, though burned rock was present. No temporally diagnostics were recovered, so we are unable to suggest dates for these prehistoric occupations.

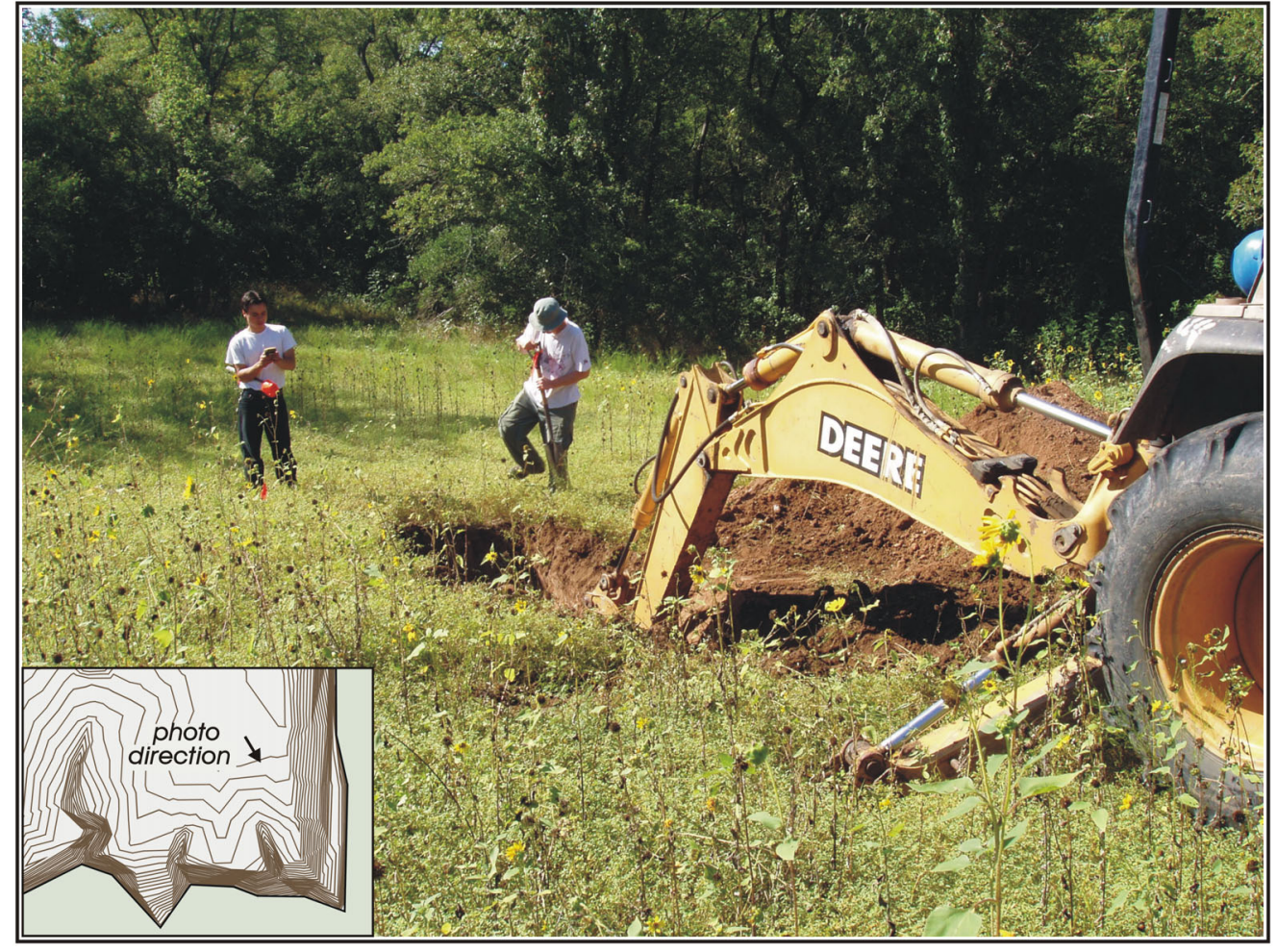

Figure 4-4. Excavation of Backhoe Trench 3 on 41 BP678. 


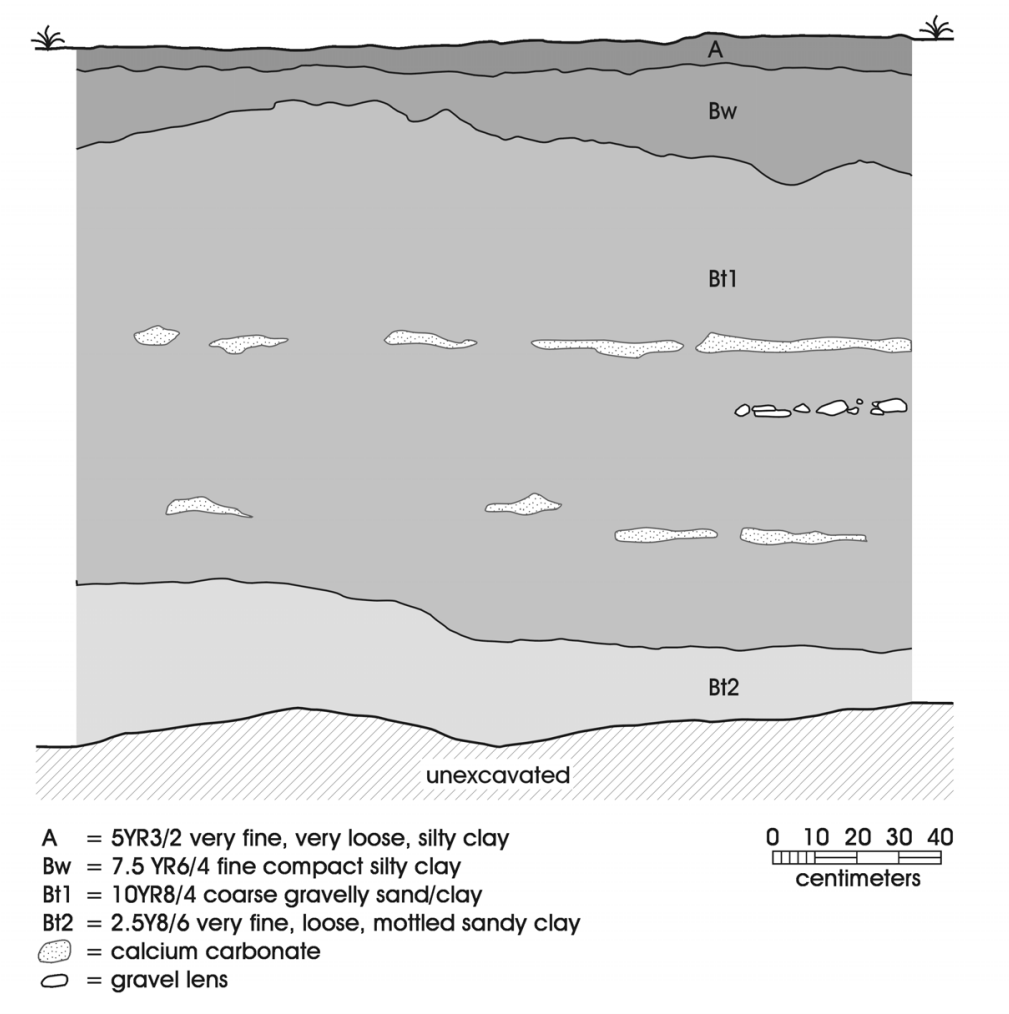

Figure 4-5. Profile of a portion of the west wall of Backhoe Trench 3.

\section{$41 \mathrm{BP} 679$}

Site 41BP679 is located along the upland slopes north of Spring Branch approximately $275 \mathrm{~m}$ west of the Colorado River. The site consists of two adjacent knolls separated by a shallow drainage (Figure 4-6). Site 41BP679 stretches approximately $195 \mathrm{~m}$ east/west by $80 \mathrm{~m}$ north/south and contains an area of approximately 2.95 acres (1.19 hectares). The southwestern portion of the site is heavily wooded and extends toward Spring Branch along a gradual slope. Due to the dense vegetation and poor visibility across the area, only two artifacts, a large bifacial preform and a core, were observed on the surface during the reconnaissance.

Two shovel tests were excavated within the site boundary, and both were positive (Table 4-2). Cultural material, consisting of chipped stone debitage and burned rock, was recovered from ST 27 from 10-20 cmbs. ST 23 contained materials at all depths from the surface to $30 \mathrm{cmbs}$. Six additional negative shovel tests were placed to the north and east of the site and aided in delineating the site boundaries (Figure 4-6).

Two backhoe trenches were excavated at 41BP679 (Figure 4-6). BHT 5 was placed on the brow of the eastern rise and four pieces of lithic debitage were observed in the backdirt. A single flake was recorded in the wall of the trench at 15 $\mathrm{cm}$ below surface. BHT 6 was excavated on the western knoll and cultural debris was abundant at that location. Due to the amount of cultural material present in the backdirt, artifacts were collected from BHT 6 . The artifacts include two bifaces, 15 pieces of lithic debitage, eight burned rock fragments, two animal bone fragments and a mussel shell fragment. Two flakes were also observed in the wall of the trench, one at $75 \mathrm{cmbs}$ and the other at $92 \mathrm{cmbs}$ (Figure 4-7). Figure 4-8 presents the two bifaces recovered from BHT 6 on 41BP679. Both are heavily patinated. The parallel flaking pattern in specimen " $b$ " in the figure is reminiscent 


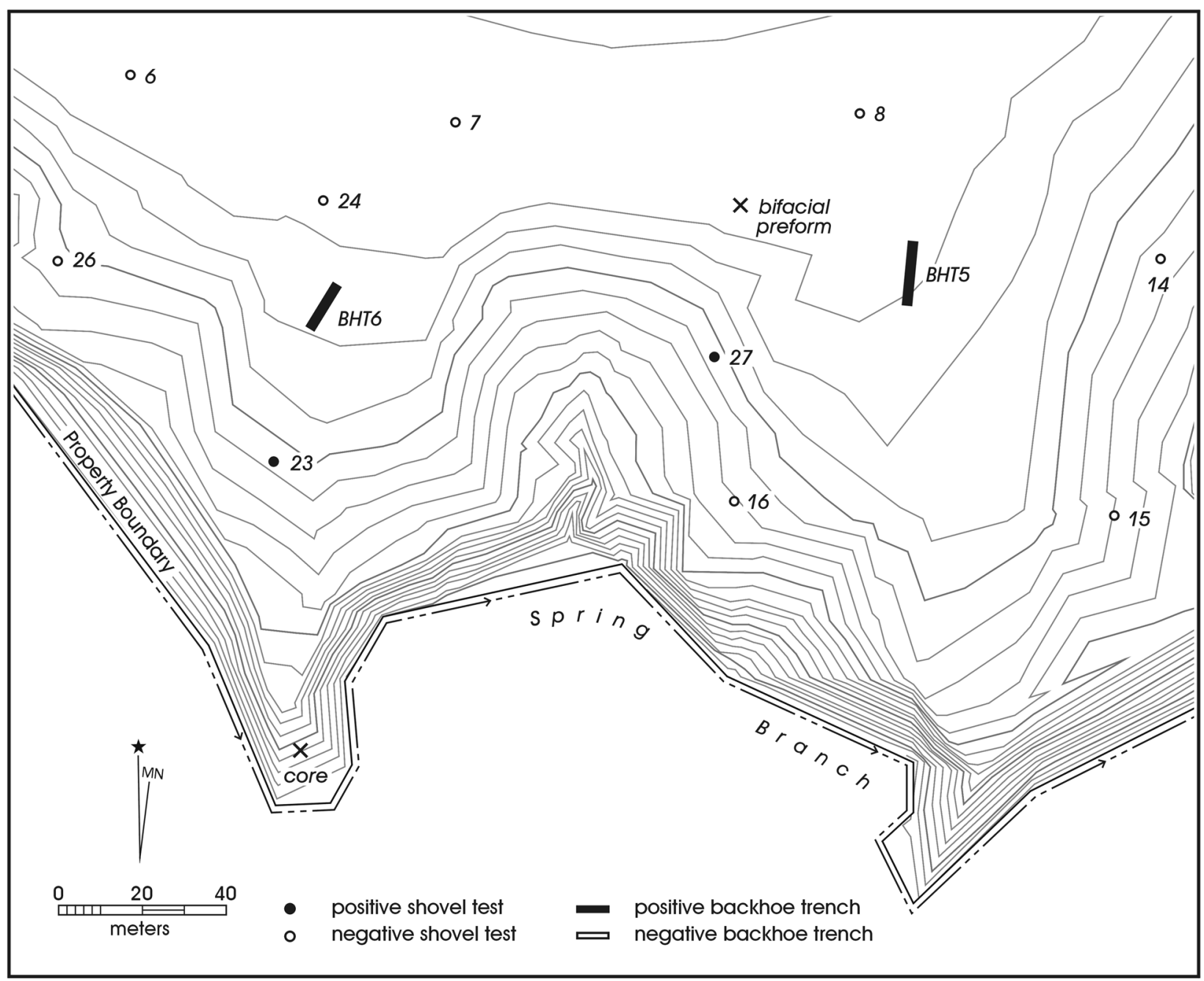

Figure 4-6. Approximate location of site 41 BP679.

Table 4-2. Shovel Test Results from 41BP679

\begin{tabular}{|c|l|c|c|}
\hline Shovel Test No. & \multicolumn{1}{|c|}{ Artifact } & Count & Level of Artifact (cmbs) \\
\hline 23 & Debitage & 2 & $1(0-10)$ \\
\hline 23 & Debitage & 1 & $2(10-20)$ \\
\hline 23 & Burned Rock & 1 & $2(10-20)$ \\
\hline 23 & Debitage & 1 & $3(20-30)$ \\
\hline 23 & Mussel Shell & 1 & $3(20-30)$ \\
\hline 27 & Debitage & 1 & $2(10-20)$ \\
\hline
\end{tabular}




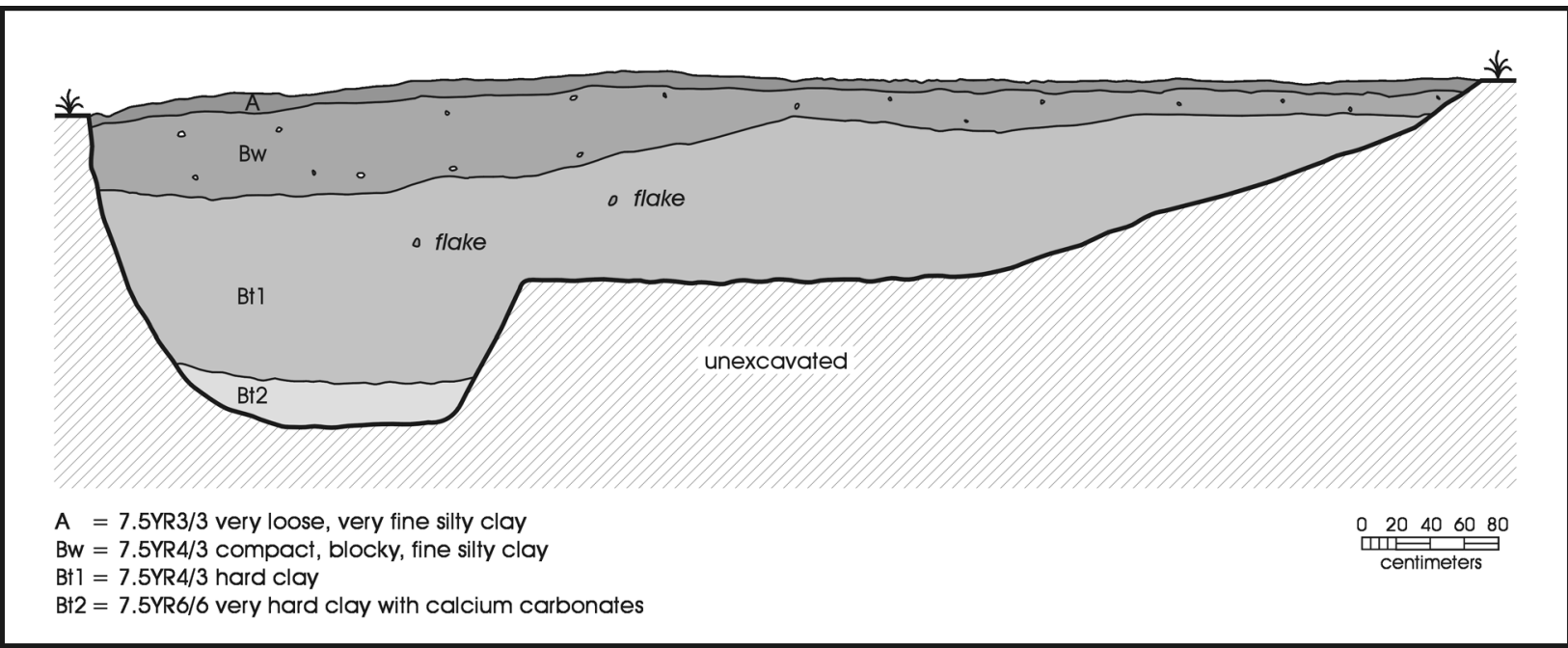

Figure 4-7. Profile of east wall of Backhoe Trench 6 at 41BP679.

of some late Paleoindian artifacts, such as Angostura points (Turner and Hester 1999:73-74). However, the broken nature of the item prevents a positive assignment to any time period.

\section{Summary}

Surface survey and shovel testing on 41BP679 produced chipped stone tools and debitage, as well as burned rock, from the surface down to $30 \mathrm{cmbs}$. Deeper archaeological deposits (ca. 75-92 cmbs), minimally consisting of debitage, are reflected in BHT 6. No features were recorded at the site, though burned rock is present. While no diagnostic artifacts were present, a broken biface was recovered from backhoe trench backdirt. The highly patinated biface has parallel flaking reminiscent of late Paleoindian forms.

\section{Isolated Find}

A single flake was recovered from Level $3(20-30 \mathrm{cmbs})$ of ST 5 in the northwest portion of the project area. Additional shovel tests were placed roughly $25 \mathrm{~m}$ to the west, south, and east, but did not yield cultural materials. Because this find did not meet our site criteria, it was classified as an isolated find.

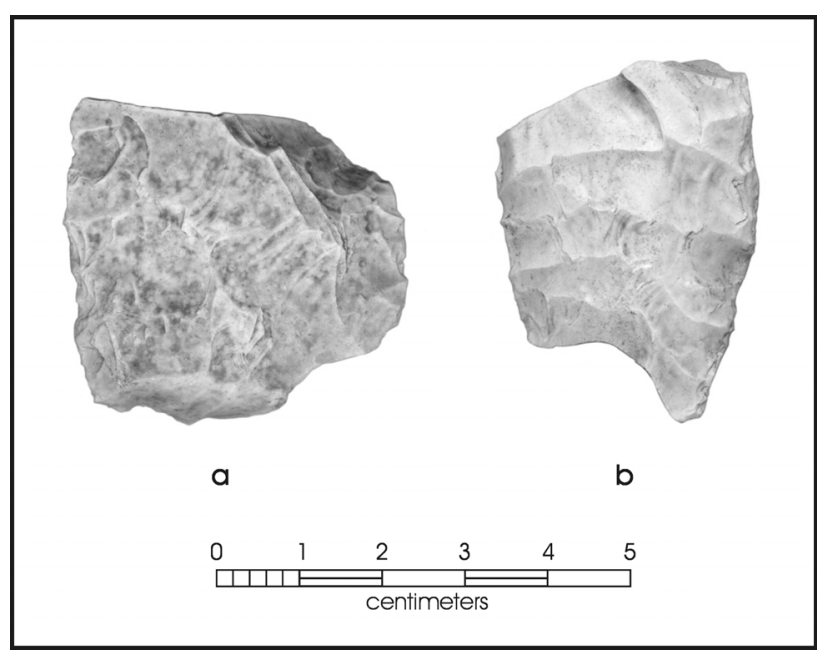

Figure 4-8. Bifaces recovered from Backhoe Trench 6 at $41 B P 679$. 


\section{Chapter 5: Recommendations}

This chapter summarizes the findings of the CAR survey and provides recommendations regarding the two archaeological sites in the context of the proposed development of the wastewater treatment plant.

A 100\% pedestrian survey and shovel testing were performed by CAR during August 2004. During the survey, two new archaeological sites (41BP678 and 41BP679) were identified and documented. The two sites are both located in the southern portion of the project area. Site 41BP678, located at the confluence of the Colorado River and a tributary, Spring Branch, consists of a light surface scatter of chipped stone debitage and buried cultural materials. Shovel tests suggest that two components may be present, with one located from the surface down to $20 \mathrm{cmbs}$, and a second located between $40 \mathrm{cmbs}$ and $60 \mathrm{cmbs}$. No features were recorded, though burned rock is present in small numbers. No temporally diagnostic artifacts were recovered. The second site (41BP679) abuts Spring Branch. Site 41BP679 consists of a light surface scatter of chipped stone, including a biface and a core, and buried cultural materials. Shovel testing demonstrated that debitage and burned rock is present down to $30 \mathrm{cmbs}$, though deeper deposits (ca. 75-92 cmbs), evidenced by two flakes observed in a backhoe trench profile, are present at the site. No features were recorded. While no diagnostic artifacts were present, a broken biface was recovered from backhoe trench backdirt. The highly patinated biface has parallel flaking reminiscent of late Paleoindian (c.f. Angostura) forms.

The proposed water treatment facility will impact limited portions of each of these sites. The gray-water outflow line will cut through roughly $109 \mathrm{~m}$ of 41BP678 and $61 \mathrm{~m}$ of 41BP679. In addition, the construction of one clarifier tank and a flume will impact small portions of 41BP679. We currently lack sufficient information on either site to make determinations of eligibility for listing on the National Register of Historic Places or for State Archeological Landmark designation. If the wastewater treatment facility cannot be moved to avoid these sites, we recommend that limited testing be conducted to determine the eligibility status of 41BP678 and 41BP679. On site 41BP678, that testing, consisting of the excavation of 1-x-1-m test units, should focus along the location of the outflow pipe. On site 41BP679, we would suggest $1-x-1-m$ test units near the northwestern corner of the site, an area that will be impacted by the construction of the clarifier tanks, and in the areas of the proposed flume building and along the path of the outflow pipe in the northeastern section of the site. These units should provide information regarding the integrity and nature of the buried deposits documented by the shovel testing and backhoe trenching discussed in the previous chapter, as well as data allowing the temporal placement of the archaeological deposits at these sites. 


\section{References Cited}

Baker, F. E.

1979 Soil Survey of Bastrop County, Texas. Soil Conservation, U.S. Department of Agriculture, Washington D.C.

Barnes, V. E.

1974 Geologic Atlas of Texas. Austin Sheet. Bureau of Economic Geology. The University of Texas at Austin.

Bement, L. C.

1989 Excavations at 41BP19: The Kennedy Bluffs Site, Bastrop County, Texas. Texas Archeological Research Laboratory, The University of Texas at Austin. Report No. 5, Highway Design Division, Texas State Department of Highways and Public Transportation, Austin.

Black, S. L.

1989 Central Texas Plateau Prairie. In From the Gulf Coast to the Rio Grande: Human Adaptation in Central, South and Lower Pecos, Texas, by T. R. Hester, S. L. Black, D. G. Steele, B. W. Olive, A. A. Fox, K. J. Reinhard, and L. C. Bement, pp. 17-38. Research Series No. 33. Arkansas Archeological Survey, Fayetteville.

Black, S. L., and A. J. McGraw

1985 The Panther Springs Creek Site: Cultural Change and Continuity in the Upper Salado Creek Drainage, SouthCentral Texas. Archaeological Survey Report, No. 100. Center for Archaeological Research, The University of Texas at San Antonio.

Blair, W. F.

1950 The Biotic Provinces of Texas. Texas Journal of Science 2(1):93-117.

Collins, M. B.

1995 Forty Years of Archeology in Texas. Bulletin of the Texas Archeological Society 66:361-400.

1998 Wilson-Leonard: An 11,000-year Archeological Record of Hunter-Gatherers in Central Texas. Studies in Archeology, Report No. 31. Texas Archeological Research Laboratory, The University of Texas at Austin. Archeology Studies Program, Report No. 10, Environmental Affairs Division, Texas Department of Transportation, Austin.

Duke, P. L.

1977 Lake Thunderbird Site (41BP78), Bastrop, Texas. La Tierra 4(3):15-26.

Gould, F. W.

1969 Texas Plants: A Checklist and Ecological Summary. Texas Agricultural Experiment Station. Publication MP585. Texas A\&M University, College Station.

Hester, T. R.

1995 The Prehistory of South Texas. Bulletin of the Texas Archeological Society 66:427-459.

Kenmotsu, N. D.

1982 Cultural Resource Investigations at the Powel Bend Prospect, Bastrop County, Texas. Research Report No. 84, Texas Archeological Survey, The University of Texas at Austin. 
Klinger, T. C., J. W. Smith, D. R. Dickson, A. J. Hawkins, and J. L. Gray, IV

1999 Texas Pipeline 2: Cultural Resource Documentation. Historic Preservation Associates Reports 99-09. Historic Preservation Associates, Fayetteville, Arkansas.

Leffler, J. J.

2001 The History of the Camp Swift Area, 1830-1950. In An Archaeological Inventory of Camp Swift, Bastrop County, Texas, pp. 14-30, by D. G. Robinson, T. M. Meade, L. Haslouer, L. Gassaway, and D. Kay, edited by B. Meissner. Archaeological Survey Report, No. 316, Center for Archaeological Research, The University of Texas at San Antonio.

Nickels, D. L., M. L. Lehman, and C. B. Bousman

2003 Archaeological Evaluation of 39 Category V Sites at Camp Swift, Bastrop County, Texas: 2001. Archaeological Studies Report No. 3. Center for Archaeological Studies, Southwest Texas State University, San Marcos, Texas.

Prewitt, E. R.

1981 Culture Chronology in Central Texas. Bulletin of the Texas Archeological Society 52:65-89.

Robinson, D. G.

1987 Bastrop County Historical Commission Sesquicentennial Project: Cultural Resource Investigations Along the Colorado River, Bastrop County, Texas. Archeology Series 2. Texas Archeological Survey, The University of Texas at Austin.

Robinson, D. G., T. M. Meade, L. Haslouer, L. Gassaway, and D. Kay

2001 An Archaeological Inventory at Camp Swift, Bastrop County, Texas, edited by B. A. Meissner. Archaeological Survey Report, No. 316, Center for Archaeological Research, The University of Texas at San Antonio.

Schmidt, J. S., and M. E, Cruse

1995 Cultural Resource Survey, Camp Swift, Bastrop County, Texas. Espey, Huston \& Associates, Inc., Austin.

Skelton, D., and M. D. Freeman

1979 Cultural Resource Inventory and Assessment at Camp Swift, Texas. Research Report No. 72. Texas Archeological Survey, The University of Texas at Austin.

Tankersley, K. B., and B. L. Isaac

1990 Early Paleoindian Economies of North America. JAI Press. Greenwich, Connecticut.

Texas Historical Commission (THC)

2004 Texas Archeological Sites Atlas. $<$ http://pedernales.thc.state.tx.us/>

The Handbook of Texas Online

2002 Bastrop County. $<$ http://www.tsha.utexas.edu/handbook/online/articles/view/BB/hcb3.html $>$ Accessed August 27, 2004.

Turner, E. S., and T. R. Hester

1999 A Field Guide to Stone Artifacts of Texas Indians. Third Edition. Gulf Publishing Co., Houston.

Wilson, A. M.

1930 Observations of Indian Life on the Colorado River. Unpublished manuscript on file at the Texas Archeological Research Laboratory, The University of Texas at Austin. 